\title{
Approaches to Conventional Mechanical Ventilation of the Patient With Acute Respiratory Distress Syndrome
}

\author{
Dean R Hess PhD RRT FAARC
}

\author{
Introduction \\ Volume and Pressure Limitation \\ The ARDS Network Higher Versus Lower Tidal Volume Study \\ Volume or Pressure Limitation? \\ Potential for Auto-PEEP \\ Pressure Controlled Versus Volume Controlled Ventilation \\ Synchrony \\ Tidal Volume Limitation in Patients Who Do Not Have ALI/ARDS \\ Is Volume and Pressure Limited Ventilation Widely Applied? \\ Prolonged Inspiratory Time and Inverse Inspiratory-Expiratory Ratio \\ Setting PEEP for ALI and ARDS \\ The Randomized Controlled Trials \\ PEEP and Potential for Recruitment \\ The Meta-Analyses \\ Approaches to Setting PEEP \\ Stress and Strain \\ Summary
}

To minimize ventilator-induced lung injury, attention should be directed toward avoidance of alveolar over-distention and cyclical opening and closure of alveoli. The most impressive study of mechanical ventilation to date is the Acute Respiratory Distress Syndrome (ARDS) Network study of higher versus lower tidal volume $\left(V_{T}\right)$, which reported a reduction in mortality from $39.8 \%$ to $31.0 \%$ with $6 \mathrm{~mL} / \mathrm{kg}$ ideal body weight rather than $12 \mathrm{~mL} / \mathrm{kg}$ ideal body weight (number-neededto-treat of 12 patients). To achieve optimal lung protection, the lowest plateau pressure and $V_{T}$ possible should be selected. What is most important is limitation of $\mathbf{V}_{T}$ and alveolar distending pressure, regardless of the mode set on the ventilator. Accumulating observational evidence suggests that $V_{T}$ should be limited in all mechanically ventilated patients-even those who do not have ALI/ARDS. Evidence does not support the use of pressure controlled inverse-ratio ventilation. Although zero PEEP is probably injurious, an area of considerable controversy is the optimal setting of PEEP. Available evidence does not support the use of higher PEEP, compared to lower PEEP, in unselected patients with acute lung injury (ALI)/ARDS. However, results of a metaanalysis using individual patients from 3 randomized controlled trials suggest that higher PEEP should be used for ARDS, whereas lower PEEP may be more appropriate in patients with ALI. PEEP should be set to maximize alveolar recruitment while avoiding over-distention. Many approaches for setting PEEP have been described, but evidence is lacking that any one approach is superior to any other. In most, if not all, cases of ALI/ARDS, conventional ventilation strategies can be used effectively to provide lung-protective ventilation strategies. Key words: acute lung injury; ALI; acute respiratory distress syndrome; ARDS; lung-protective ventilation strategies; mechanical ventilation; PEEP; ventilator-induced lung injury. [Respir Care 2011;56(10):1555-1572. (C) 2011 Daedalus Enterprises] 


\section{Introduction}

Many lives have been saved by the use of mechanical ventilation. But after years of targeting ventilation strategies to normalize arterial blood gases, it was realized that these strategies might result in ventilator-induced lung injury (VILI). Lung-protective ventilation strategies have recently received increasing attention and are now considered standard practice. There are 2 principal causes of VILI: alveolar over-distention, and cyclical opening and closing of alveoli. Injurious ventilation strategies cause increased permeability of the alveolar-capillary membrane and increased production of pro-inflammatory mediators within the lungs. Leakage of the inflammatory mediators into the bloodstream can result in downstream organ system failures, which can lead ultimately to multiple organ failure and death. ${ }^{1-6}$ Lung-protective ventilation strategies are directed primarily toward volume and pressure limitation during the inspiratory phase and maintenance of alveolar recruitment during the expiratory phase. The purpose of this paper is to review the evidence supporting lung-protective ventilation using conventional ventilation strategies.

\section{Volume and Pressure Limitation}

\section{The ARDS Network Higher Versus Lower Tidal Volume Study}

In the late 20th century, many experimental studies were published suggesting benefit from tidal volume $\left(\mathrm{V}_{\mathrm{T}}\right)$ limitation. ${ }^{7}$ Several patient studies reported that $\mathrm{V}_{\mathrm{T}}$ limitation was safe, ${ }^{8-10}$ and a single-center study from Brazil found that inspiratory volume and pressure limitation with higher PEEP was associated with a survival benefit. ${ }^{11}$ This led to funding by the National Institutes of Health for the Acute Respiratory Distress Syndrome (ARDS) Network to study ventilation with lower $\mathrm{V}_{\mathrm{T}}$, as compared with traditional $\mathrm{V}_{\mathrm{T}}$, for patients with acute lung injury (ALI) and ARDS. ${ }^{12,13}$

Dr Hess is affiliated with Respiratory Care Services, Massachusetts General Hospital, Harvard Medical School, Boston, Massachusetts.

Dr Hess presented a version of this paper at the 26th New Horizons Symposium, "ARDS Update," at the 56th International Respiratory Congress of the American Association for Respiratory Care, held December 6-9, 2010, in Las Vegas, Nevada.

Dr Hess has disclosed relationships with Philips Respironics, Covidien, ResMed, Pari, and Breathe Technologies.

Correspondence: Dean R Hess PhD RRT FAARC, Respiratory Care, Ellison 401, Massachusetts General Hospital, 55 Fruit Street, Boston MA 02114. E-mail: dhess@partners.org.

DOI: $10.4187 /$ respcare.01387
Patients were recruited from March 1996 through March 1999 at 10 university hospitals in the United States. Volume controlled continuous mandatory ventilation was used and $\mathrm{V}_{\mathrm{T}}$ was set based on ideal body weight (IBW). In the group treated with traditional $\mathrm{V}_{\mathrm{T}}$ the target $\mathrm{V}_{\mathrm{T}}$ was $12 \mathrm{~mL} / \mathrm{kg}$ IBW. This was subsequently reduced, if necessary, to maintain plateau pressure $\left(\mathrm{P}_{\text {plat }}\right) \leq 50 \mathrm{~cm} \mathrm{H}_{2} \mathrm{O}$. In the group treated with lower $\mathrm{V}_{\mathrm{T}}$, the target $\mathrm{V}_{\mathrm{T}}$ was reduced to $6 \mathrm{~mL} / \mathrm{kg}$ IBW and subsequently reduced, as necessary, to maintain $\mathrm{P}_{\text {plat }} \leq 30 \mathrm{~cm} \mathrm{H}_{2} \mathrm{O}$. The minimum $\mathrm{V}_{\mathrm{T}}$ was $4 \mathrm{~mL} / \mathrm{kg} \mathrm{IBW}$. If $\mathrm{P}_{\text {plat }}$ dropped below $25 \mathrm{~cm} \mathrm{H}_{2} \mathrm{O}, \mathrm{V}_{\mathrm{T}}$ was increased in steps of $1 \mathrm{~mL} / \mathrm{kg} \mathrm{IBW}$ until $\mathrm{P}_{\text {plat }}$ was at least $25 \mathrm{~cm} \mathrm{H}_{2} \mathrm{O}$ or the $\mathrm{V}_{\mathrm{T}}$ was $6 \mathrm{~mL} / \mathrm{kg}$ IBW. For patients with severe dyspnea, the $\mathrm{V}_{\mathrm{T}}$ could be increased to $8 \mathrm{~mL} / \mathrm{kg} \mathrm{IBW}$.

The results of the ARDS Network study are impressive-perhaps the most impressive of any study of mechanical ventilation to date. The trial was stopped after the enrollment of 861 patients because mortality was lower in the group treated with lower $\mathrm{V}_{\mathrm{T}}$ than in the group treated with traditional $\mathrm{V}_{\mathrm{T}}(31.0 \%$ vs $39.8 \%, P=.007)$. Translated to the metrics of evidence-based medicine, the number of patients needed to treat with the lower $\mathrm{V}_{\mathrm{T}}$ to avoid a single death is 12 patients. The number of ventilator-free days during the first 28 days after randomization was greater in the lower- $\mathrm{V}_{\mathrm{T}}$ group $(12 \pm 11 \mathrm{~d}$ vs $10 \pm 11 \mathrm{~d}, P=.007)$. The mean $\mathrm{P}_{\text {plat }}$ was $25 \pm 6 \mathrm{~cm} \mathrm{H}_{2} \mathrm{O}$ in the lower- $\mathrm{V}_{\mathrm{T}}$ group and $33 \pm 8 \mathrm{~cm} \mathrm{H}_{2} \mathrm{O}$ in the higher- $\mathrm{V}_{\mathrm{T}}$ group $(P<.001)$. The results of this study clearly demonstrate that, in patients with ALI/ARDS, mechanical ventilation with a lower $\mathrm{V}_{\mathrm{T}}$ and $\mathrm{P}_{\text {plat }}$ decreases mortality and ventilator days.

\section{Volume or Pressure Limitation?}

Whether the actual $\mathrm{V}_{\mathrm{T}}$ used should be based on the individual patient's lung mechanics, specifically $\mathrm{P}_{\text {plat }}$, rather than a $\mathrm{V}_{\mathrm{T}}$ of $4-8 \mathrm{~mL} / \mathrm{kg}$ has been debated. ${ }^{14}$ The argument in favor of $\mathrm{P}_{\text {plat }}$ rather than $\mathrm{V}_{\mathrm{T}}$ limitation questions the value of $\mathrm{V}_{\mathrm{T}}$ reduction in patients with ALI/ARDS whose $\mathrm{P}_{\text {plat }}$ is $<30 \mathrm{~cm} \mathrm{H}_{2} \mathrm{O}$. To address this question, Hager et a ${ }^{15}$ performed a secondary analysis of data from the ARDS Network. They found a beneficial effect of $\mathrm{V}_{\mathrm{T}}$ reduction from $12 \mathrm{~mL} / \mathrm{kg}$ to $6 \mathrm{~mL} / \mathrm{kg}$, regardless of the $\mathrm{P}_{\text {plat }}$ before the $\mathrm{V}_{\mathrm{T}}$ reduction (Fig. 1). ${ }^{16}$ Patients enrolled in the ARDS Network study were divided into quartiles of $\mathrm{P}_{\text {plat }}$. Using a logistic regression model, lower $\mathrm{P}_{\text {plat }}$ quartile, and lower Acute Physiology and Chronic Health Evaluation III score were significant predictors of lower mortality. However, the interaction between $\mathrm{V}_{\mathrm{T}}$ and $\mathrm{P}_{\text {plat }}$ quartile was not significant. Thus, patients in the $12 \mathrm{~mL} / \mathrm{kg}$ PBW $V_{T}$ group would have benefited from $V_{T}$ reduction in each of the quartiles, even those in which $\mathrm{P}_{\text {plat }}$ was already $<31 \mathrm{~cm} \mathrm{H}_{2} \mathrm{O}$.

Terragni et a ${ }^{17}$ performed computed tomography (CT) at end-expiration and end-inspiration in 30 patients venti- 


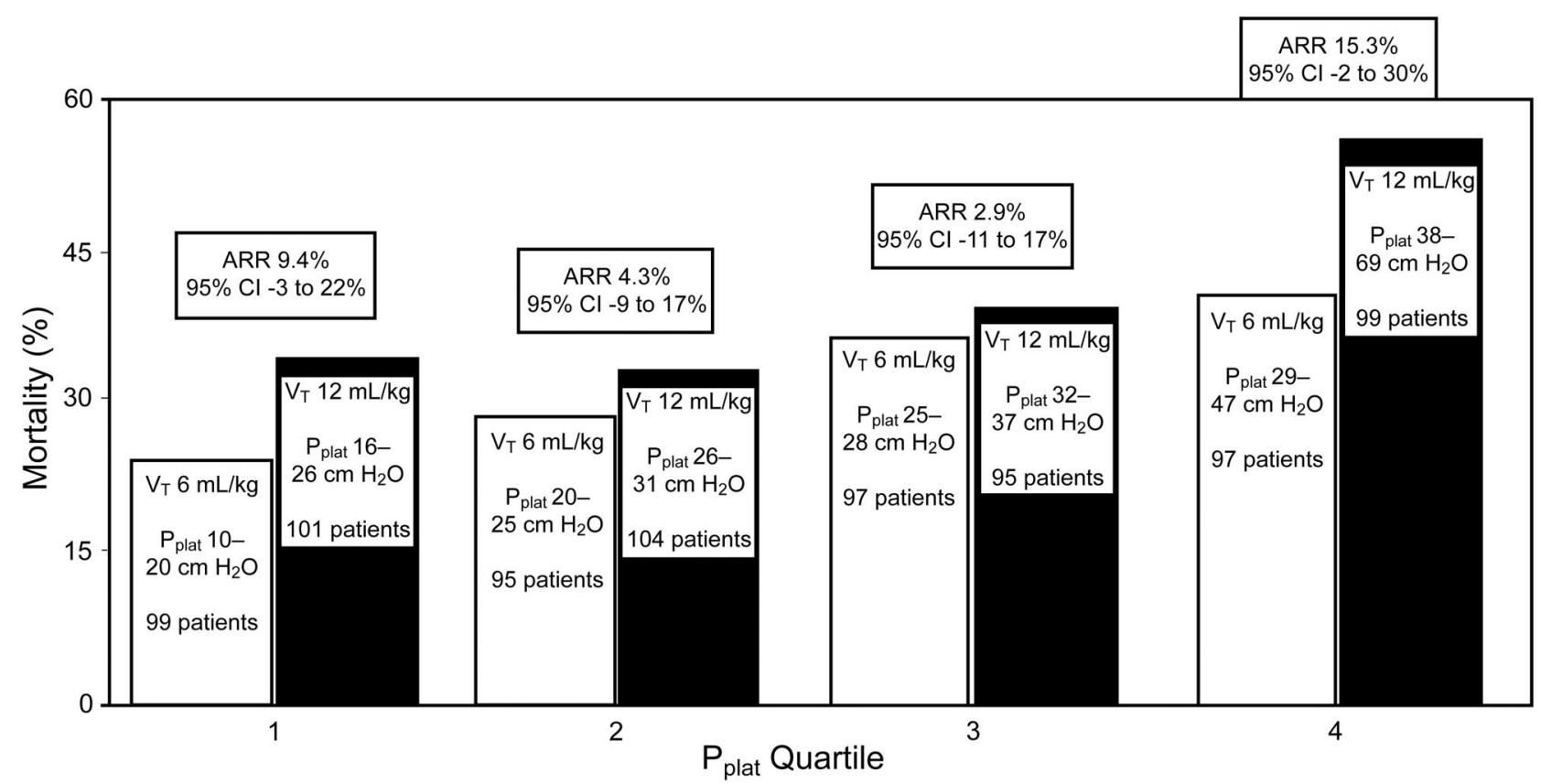

Fig. 1. Mortality versus quartile of day-1 plateau pressure $\left(P_{\text {plat }}\right)$ at tidal volume $\left(V_{T}\right)$ of $6 \mathrm{~mL} / \mathrm{kg}$ ideal body weight (IBW) or $12 \mathrm{~mL} / \mathrm{kg}$ IBW. The bars show the $\mathrm{V}_{\mathrm{T}}$, the $\mathrm{P}_{\text {plat }}$ range, and the number of patients in each category. $A R R=$ absolute risk reduction. (Data from Reference 76 . Adapted from Reference 16, with permission.)

lated with a $\mathrm{V}_{\mathrm{T}}$ of $6 \mathrm{~mL} / \mathrm{kg}$ IBW. They identified 20 of these patients in whom tidal inflation occurred largely in the normally aerated parts of the lungs, and 10 patients in whom tidal inflation occurred largely within the hyperinflated compartments. The non-aerated compartment was smaller and the normally aerated compartment was larger in the more protected patients than in the less protected patients. Pulmonary cytokines were lower in the more protected patients than in the less protected patients. Ventilator-free days were $7 \pm 8$ days and $1 \pm 2$ days in the more protected and less protected patients, respectively. $\mathrm{P}_{\text {plat }}$ was $25-26 \mathrm{~cm} \mathrm{H}_{2} \mathrm{O}$ in the more protected patients and $28-30 \mathrm{~cm} \mathrm{H}_{2} \mathrm{O}$ in the less protected patients. These results suggest that limiting $\mathrm{V}_{\mathrm{T}}$ to $6 \mathrm{~mL} / \mathrm{kg}$ IBW and $\mathrm{P}_{\text {plat }}$ $<30 \mathrm{~cm} \mathrm{H}_{2} \mathrm{O}$ may not be sufficient in patients characterized by a larger non-aerated compartment.

The findings of Hager et $\mathrm{al}^{15}$ and Terragni et al ${ }^{17}$ suggest that there might not be a safe $\mathrm{P}_{\text {plat }}$ in patients with ALI/ARDS. To achieve optimal lung protection, the lowest $P_{\text {plat }}$ and $V_{T}$ possible should be selected. This is limited by the degree of permissive hypercapnia that the clinician is willing to accept. It has been suggested, primarily from experimental models, that permissive hypercapnia may be protective. ${ }^{18}$ Kregenow et $\mathrm{al}^{19}$ evaluated the effect of hypercapnic acidosis in a secondary analysis of the ARDS Network database. They found that hypercapnic acidosis was associated with reduced 28-day mortality in the $12 \mathrm{~mL} / \mathrm{kg} \mathrm{IBW} \mathrm{V}_{\mathrm{T}}$ group, after controlling for comorbidities and severity of lung injury. However, this was not found when the further ongoing injury was reduced by $6 \mathrm{~mL} / \mathrm{kg}$ predicted body weight $\mathrm{V}_{\mathrm{T}}$.

\section{Potential for Auto-PEEP}

To prevent acidosis with low- $\mathrm{V}_{\mathrm{T}}$ ventilation, higher than normal respiratory rates are set—as high a 35 breaths/min in the ARDS Network study. ${ }^{13}$ This has raised concern about the development of auto-PEEP. ${ }^{20}$ However, when data from patients enrolled in the ARDS Network study were examined, the level of auto-PEEP was minimal. ${ }^{18}$ This, in fact, is predictable. Although a high respiratory rate is expected to shorten the expiratory time, the inspiratory time is shorter due to the smaller $\mathrm{V}_{\mathrm{T}}$. In addition, the low compliance (high elastance) in ALI/ARDS results in a greater elastic recoil pressure pushing gas out of the lungs during exhalation.

\section{Pressure Controlled Versus Volume Controlled Ventilation}

One of the ongoing debates is whether pressure controlled ventilation (PCV) should be used a part of lungprotective ventilation strategy. ${ }^{21}$ There are advantages and disadvantages to either PCV or volume controlled ventilation (VCV) (Table 1). Purists will argue that the ARDS Network study was conducted with VCV; to achieve similar results, one should apply the evidence in the same way 
Table 1. Volume Controlled Versus Pressure Controlled Ventilation

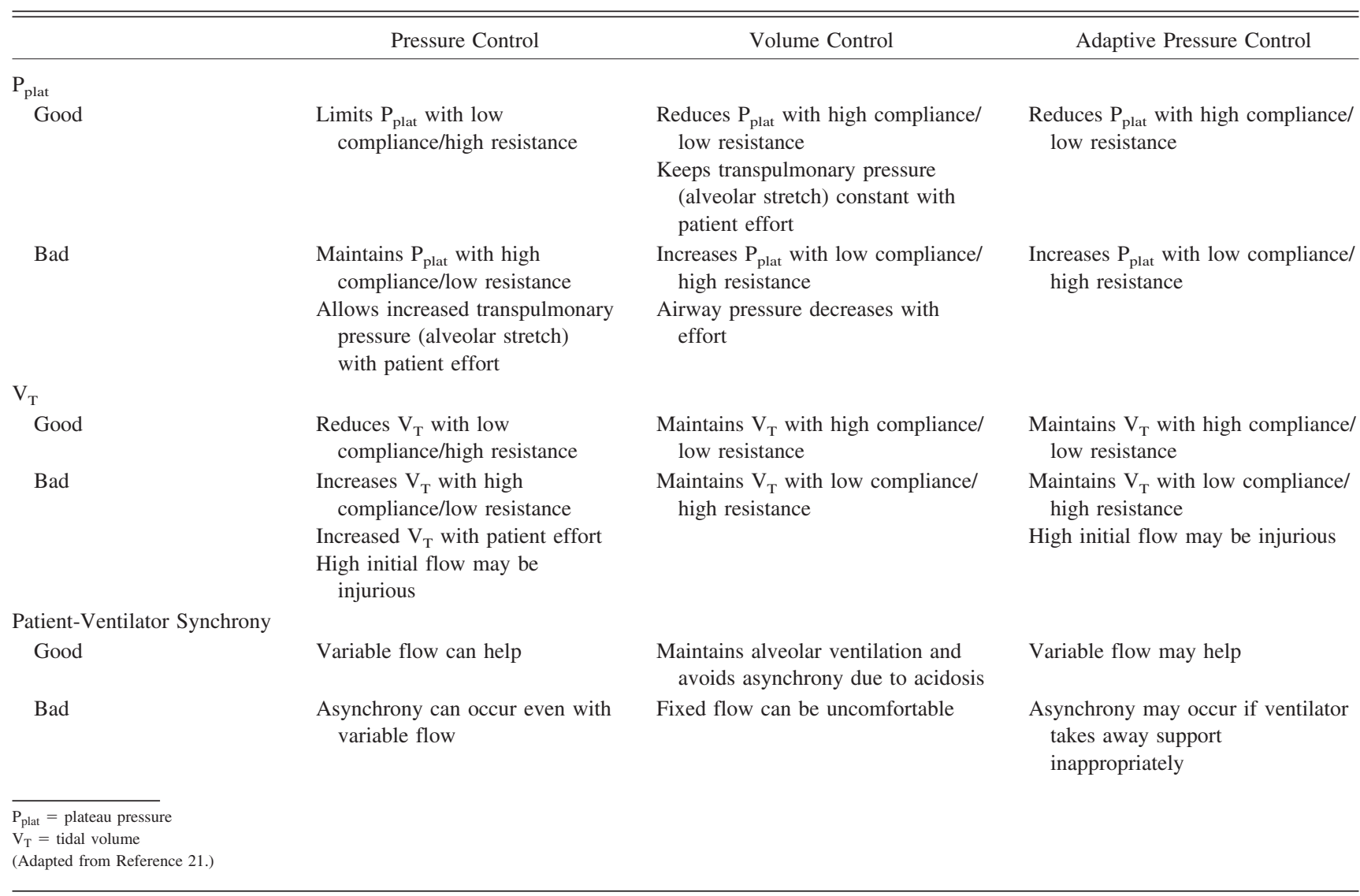

as was done in the predicate study. However, others will argue that some advantages might exist with PCV. With $\mathrm{PCV}, \mathrm{P}_{\text {plat }}$ can never be greater than the peak inspiratory pressure. The square wave of inspiratory pressure with PCV will result in a higher mean airway pressure, which might improve ventilation/perfusion matching and $\mathrm{P}_{\mathrm{aO}_{2}}$. Moreover, the flow pattern is an exponential decay, which might improve distribution of ventilation, ventilation/perfusion matching, and $\mathrm{P}_{\mathrm{aO}}$. Finally, the variable inspiratory flow has the potential to improve patient-ventilator synchrony.

Despite many clinicians having a bias in favor of PCV in patients with ALI/ARDS, evidence supporting the superiority of $\mathrm{PCV}$ in this setting is weak. For the same $\mathrm{V}_{\mathrm{T}}$, the same inspiratory time, and a descending ramp of flow with VCV, the differences in $\mathrm{P}_{\mathrm{aO}}$, between PCV and VCV are trivial. ${ }^{22}$ Experimental models of ALI/ARDS suggest that the high initial flow that occurs with PCV might be injurious rather than lung-protective. ${ }^{23-25}$

Whether synchrony is better with PCV than VCV is also debatable. Some have reported better synchrony with PCV, ${ }^{26,27}$ but this has not been confirmed by others. ${ }^{28}$
Adaptive pressure control modes might be particularly problematic, as they can take away support for the patient if respiratory drive is high and the resultant $\mathrm{V}_{\mathrm{T}}$ exceeds the target. ${ }^{29-33}$ Some clinicians are attracted to PCV because it allows the patient to increase $\mathrm{V}_{\mathrm{T}}$ if respiratory drive increases. However, this may make it difficult to avoid alveolar over-distention and maintain lung-protective ventilation. ${ }^{28,34}$ Indeed, Leray et $\mathrm{al}^{35}$ report a case in which a patient recovering from ARDS was switched from VCV $\left(\mathrm{V}_{\mathrm{T}} 6 \mathrm{~mL} / \mathrm{kg} \mathrm{IBW}\right)$ to pressure support ventilation. With pressure support ventilation the $\mathrm{V}_{\mathrm{T}}$ increased to $14 \mathrm{~mL} / \mathrm{kg}$ and the patient developed air leaks. When VCV was restored, the air leaks resolved. This makes the point that $\mathrm{V}_{\mathrm{T}}$ can become excessive with pressure-targeted modes. Although PCV maintains a constant pressure applied to the airway, any additional effort from the patient will lower the pleural pressure, and the transpulmonary pressure will increase (Fig. 2). ${ }^{34}$

In the hands of a skilled clinician, either VCV or PCV can probably be applied in a lung-protective manner. What is most important is limitation of $\mathrm{V}_{\mathrm{T}}$ and alveolar distending pressure, regardless of the mode set on the ventilator. 


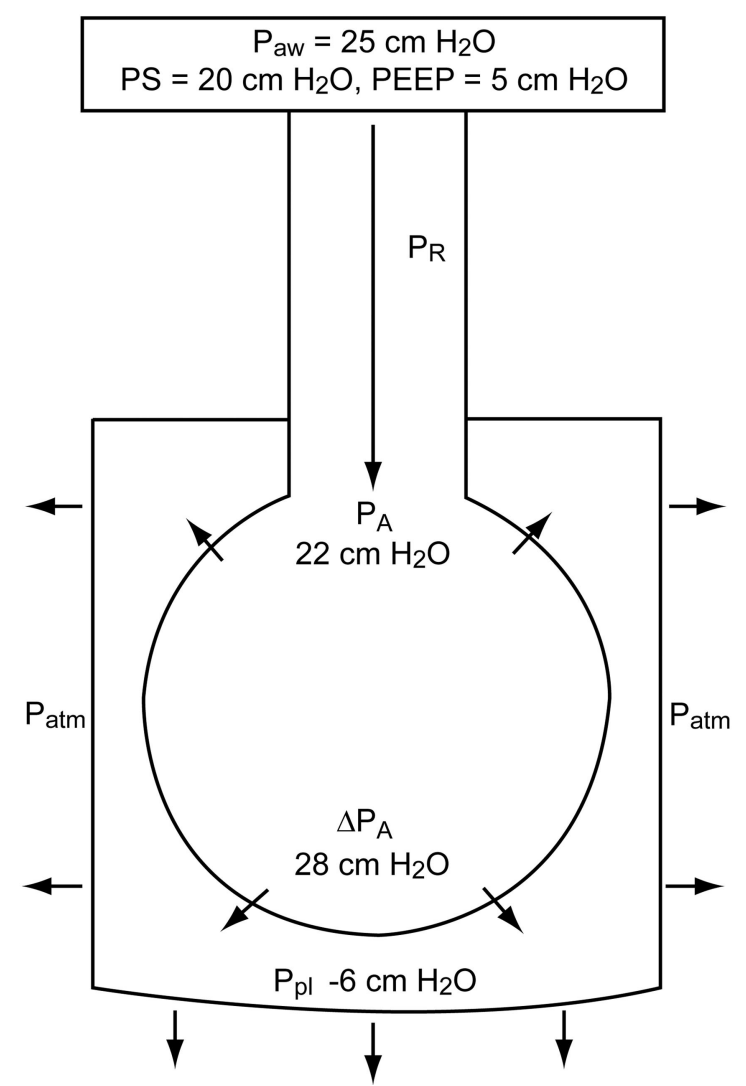

Fig. 2. Estimation of transpulmonary pressure during spontaneous breathing on pressure-targeted ventilation. Note that the pressure across the alveolus is determined not only by the pressure applied to the airway, but also by the change in pleural pressure. $P_{\text {aw }}=$ proximal airway pressure. $\mathrm{PS}=$ pressure support. $\mathrm{P}_{\mathrm{R}}=$ pressure drop due to airways resistance. $\mathrm{P}_{\mathrm{A}}=$ alveolar pressure. $\Delta \mathrm{P}_{\mathrm{A}}=$ transalveolar pressure. $\mathrm{P}_{\mathrm{atm}}=$ atmospheric pressure. $\mathrm{P}_{\mathrm{pl}}=$ pleural pressure. (Adapted from Reference 34, with permission.)

\section{Synchrony}

It is the perception of many clinicians that patientventilator asynchrony ensues when $\mathrm{V}_{\mathrm{T}}$ is reduced to $6 \mathrm{~mL} / \mathrm{kg}$. Why this should occur is unclear. A normal $\mathrm{V}_{\mathrm{T}}$ is $6-8 \mathrm{~mL} / \mathrm{kg}$, so it would seem that this $\mathrm{V}_{\mathrm{T}}$ should be comfortable during mechanical ventilation. There are several potential reasons why a $\mathrm{V}_{\mathrm{T}}$ of $6-8 \mathrm{~mL} / \mathrm{kg}$ might not be comfortable with ALI/ARDS. First, dead space is increased with ALI/ARDS, and thus respiratory acidosis will occur unless minute ventilation is increased. ${ }^{36-40}$ In the ARDS Network study, ${ }^{13}$ respiratory rates up to 35 breaths/min were used in an attempt to avoid acidosis. Other potential reasons for asynchrony are pain and anxiety due to endotracheal intubation and the disease process. Thus, adequate attention should be given to address these discomforts.

With low- $\mathrm{V}_{\mathrm{T}}$ ventilation the inspiratory time may be very short. This can produce an inspiratory time set on the ventilator that is less than the neural inspiratory time of the patient. The result is that the patient will double-trigger the ventilator. During VCV, a double-trigger can result in breath stacking and double the desired $\mathrm{V}_{\mathrm{T}}$. This effectively negates the intent of volume and pressure limitation. In one study it was reported that double-triggering is common during low- $\mathrm{V}_{\mathrm{T}}$ ventilation. ${ }^{41}$

A number of strategies can be used to improve patientventilator synchrony during lung-protective ventilation ( $\mathrm{Ta}$ ble 2). ${ }^{42,43} \mathrm{~A}$ recent study ${ }^{44}$ reported improved outcomes with paralysis for the first 48 hours following intubation in patients with ARDS. The mechanism to explain this benefit is unclear, but may be related to improved ability to apply lung-protective ventilation strategies in the early phase of the disease process. A common perception of clinicians is that there is a greater requirement for sedation with low- $\mathrm{V}_{\mathrm{T}}$ ventilation. That sedative doses were found to be similar for patients randomized to $6 \mathrm{~mL} / \mathrm{kg}$ versus $12 \mathrm{~mL} / \mathrm{kg} \mathrm{V}_{\mathrm{T}}$ in 2 ARDS Network centers supports the conclusion that sedative needs may be largely determined by clinical factors other than ventilation strategy. ${ }^{45,46}$

\section{Tidal Volume Limitation in Patients Who Do Not Have ALI/ARDS}

Although the evidence is clear and conclusive for volume and pressure limitation in patients with ALI/ARDS, should we limit the $\mathrm{V}_{\mathrm{T}}$ in all patients? There are currently no randomized controlled trials that address this question, but accumulating observational evidence suggests that $\mathrm{V}_{\mathrm{T}}$ should be limited in all mechanically ventilated patients. ${ }^{47-51}$

Yilmaz et al ${ }^{51}$ reported the results of a quality-assurance project in which an interdisciplinary team of intensivists and respiratory therapists designed a protocol to limit $\mathrm{V}_{\mathrm{T}}$ to a maximum of $10 \mathrm{~mL} / \mathrm{kg}$ IBW in all patients receiving invasive ventilation, with a recommendation to use $6-8 \mathrm{~mL} / \mathrm{kg}$ for patients at any risk of ALI/ARDS. A chart with calculated values of IBW was attached to each ventilator and it was also provided online. Comprehensive didactic and Web-based teaching was provided to physicians, nurses, and respiratory therapists involved in the care of mechanically ventilated patients. This protocol was implemented along with a protocol to limit transfusions. With implementation of this protocol the frequency of ALI decreased from $28 \%$ to $10 \%$, the duration of mechanical ventilation decreased from a median of 5 days to 4 days, and, in a multivariate logistic regression analysis, the intervention was associated with a reduction in the frequency of new ALI (odds ratio 0.21, 95\% CI 0.10-0.40). These results suggest that ALI may be, to a large extent, iatrogenic and might be preventable through relatively simple interventions such as limitation of $\mathrm{V}_{\mathrm{T}}$. Recent studies have also reported benefit for $\mathrm{V}_{\mathrm{T}}$ limitation in patients with severe brain injury ${ }^{52,53}$ and in potential organ donors with 
Table 2. Approaches to Patient-Ventilator Asynchrony

1. Sedation, Analgesia, Paralysis

Appropriate sedation and analgesia are necessary during mechanical ventilation, regardless of tidal volume. Factors such as agitation, delirium, metabolic acidosis, drug withdrawal, septic encephalopathy, and pain need to be considered. Neuromuscular blocking agents should be considered in the 48 hours following intubation; otherwise, paralysis used to achieve patient-ventilator synchrony only if sedation and analgesia are insufficient and when other methods described here have been exhausted.

2. Respiratory Rate

An increase in respiratory rate setting on the ventilator may match the breathing pattern of the patient to the ventilator, thereby enhancing synchrony. Increasing the respiratory rate setting decreases work of breathing and increases patient comfort. During transition to lower-tidalvolume ventilation, the respiratory rate should be increased as tidal volume is decreased, to maintain constant minute ventilation (maximum 35 breaths/min).

3. Tidal Volume

An increase in tidal volume, if accompanied by an increase in alveolar ventilation, decreases respiratory drive. The ARDS Network protocol allows tidal volume to be increased to $8 \mathrm{~mL} / \mathrm{kg}$ ideal body weight in the case of asynchrony and severe dyspnea, provided plateau pressure is $\leq 30 \mathrm{~cm} \mathrm{H}_{2} \mathrm{O}$.

4. Trigger Sensitivity

Set trigger as sensitive (as low) as possible without causing auto-triggering.

5. Auto-PEEP

Minimize the amount of auto-PEEP (set appropriate inspiratory-expiratory ratio, minimize airways resistance).

6. Inspiratory Flow

An increase in set inspiratory flow may better meet the flow demand of the patient and improve patient comfort. A higher inspiratory flow also decreases neural inspiratory time, however, resulting in a greater spontaneous breathing frequency, which can further contribute to asynchrony. In this case a lower inspiratory flow may be appropriate.

7. Inspiratory Time

A shorter inspiratory time (higher inspiratory flow during volume controlled ventilation) may improve patient-ventilator synchrony. If the inspiratory time setting on the ventilator is less than the neural inspiratory time, however, double-triggering and worsening asynchrony may occur. In this case, a longer inspiratory time may be appropriate.

8. Flow Waveform

Asynchrony may improve with a descending flow waveform in some patients. For the same peak flow, inspiratory time is longer with a descending flow, which may achieve the goal of better synchrony because of the higher flow, while avoiding double-triggering secondary to an inspiratory time that is too short.

9. Pressure Controlled Ventilation (PCV)

PCV achieves the goals of a descending flow waveform and an adjustable inspiratory time. PCV may result in better synchrony in some patients. A potential limitation of PCV is the possibility that transpulmonary pressure (an important determinant of volutrauma) may increase because of the generation of high negative intrapleural pressure swings, consequently increasing delivered tidal volume. For the same tidal volume and inspiratory flow, work of breathing is probably the same for PCV and volume controlled ventilation.

10. Pressure Rise Time

With PCV the clinician can adjust the rate of pressure rise at the onset of the inspiratory phase. Faster rise time may affect work of breathing and patient comfort.

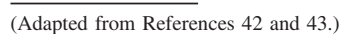

brain death, ${ }^{54}$ where it increased the number of eligible and harvested lungs compared with a conventional strategy using higher $\mathrm{V}_{\mathrm{T}}$.

\section{Is Volume and Pressure Limited Ventilation Widely Applied?}

Volume and pressure limitation, at least for ALI/ARDS, should be standard practice. Some reports published soon after publication of the ARDS Network study found only a modest change in the prescribed $\mathrm{V}_{\mathrm{T}}{ }^{55,56}$ However, more recent studies have not confirmed those findings. Esteban et al ${ }^{57}$ reported that in 2004, compared with $1998, \mathrm{~V}_{\mathrm{T}}$ decreased significantly in patients with ARDS $(7.4 \mathrm{~mL} / \mathrm{kg}$ vs $9.1 \mathrm{~mL} / \mathrm{kg}, P<.001)$. Checkley et $\mathrm{al}^{58}$ reported a gradual and ultimately substantial effect on lowering of $\mathrm{V}_{\mathrm{T}}$ at ARDS Network hospitals after completion of the study. However, these findings may not be generalizable to nonenrolled patients or to patients from other hospitals.

Adoption of lower- $\mathrm{V}_{\mathrm{T}}$ ventilation may be improved with feedback and education on lung-protective mechanical ventilation. Even a costly intervention to improve adherence to low- $\mathrm{V}_{\mathrm{T}}$ ventilation in patients with ALI reduces death and is cost-effective by current societal standards. ${ }^{59}$ Recording $\mathrm{V}_{\mathrm{T}}$ in $\mathrm{mL} / \mathrm{kg}$ IBW rather than the more traditional approach of absolute $\mathrm{V}_{\mathrm{T}}$ might draw clinician attention to excessive $V_{T}$. Similarly, recording $P_{\text {plat }}$ rather than peak inspiratory pressure alone may draw clinicians' attention to excessive distending pressure. A recent study described the use of a computer system to alert bedside providers 
Table 3. Tables Used to Set Combinations of $\mathrm{F}_{\mathrm{IO}_{2}}$ and PEEP in the ARDS Network Study

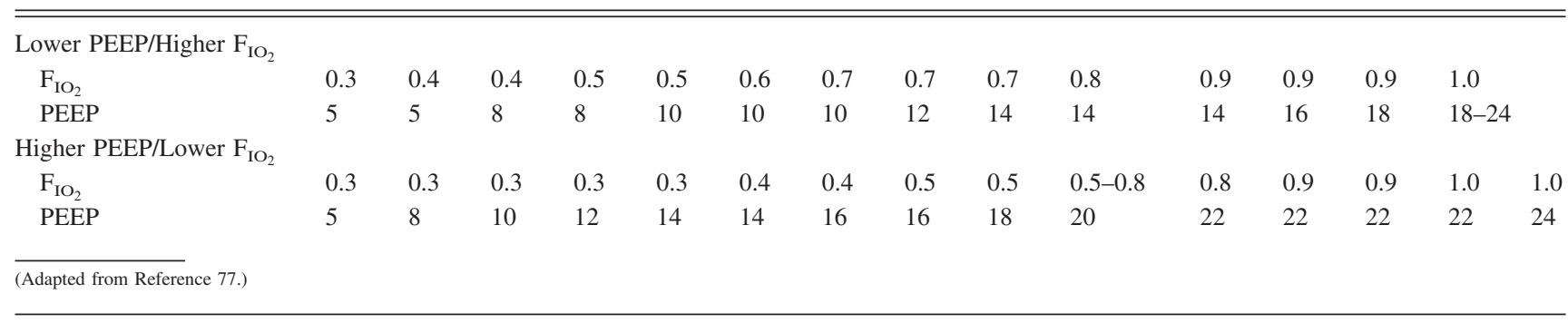

(respiratory therapists and critical care fellows) by text paging notification about potentially injurious ventilator settings. This was associated with decreased patient exposure to potentially injurious settings. ${ }^{60}$

\section{Prolonged Inspiratory Time and Inverse Inspiratory-Expiratory Ratio}

In the mid-1980s there were reports of improved oxygenation with pressure controlled inverse-ratio ventilation (PCIRV), ${ }^{61-65}$ and for some time in the decade thereafter there was enthusiasm for this method. With PCIRV, an inspiratory time greater than the expiratory time is used to increase mean airway pressure and thus improve arterial oxygenation. Although inverse-ratio ventilation is most often used with PCV, VCV with inverse ratio has also been described. ${ }^{66}$ Following the initial enthusiasm for this approach, a number of subsequent controlled studies reported no benefit or marginal benefit of PCIRV over more conventional approaches to ventilator support in patients with ARDS. ${ }^{67-71}$ A disadvantage of this approach is that the auto-PEEP that occurs with PCIRV may adversely affect hemodynamics. Because this approach is uncomfortable for the patient, sedation and paralysis are often required. Based on the available evidence, there is no clear benefit for PCIRV in the management of patients with ARDS. The improvement in oxygenation PCIRV is small and the risk of auto-PEEP and hemodynamic compromise is great. ${ }^{72-74}$

\section{Setting PEEP for ALI and ARDS}

Most patients who require mechanical ventilation for ALI/ARDS receive PEEP of 5-12 $\mathrm{cm} \mathrm{H}_{2} \mathrm{O}$. 57,75 PEEP $<5 \mathrm{~cm} \mathrm{H}_{2} \mathrm{O}$ is probably harmful, at least in the early stages of the disease process. ${ }^{76}$ Higher PEEP may improve oxygenation and reduce VILI, due to better alveolar recruitment. But higher PEEP may also cause lung injury from over-distention. A matter of controversy is how to set PEEP for patients with ALI/ARDS.

\section{The Randomized Controlled Trials}

To date, 6 clinical trials have assessed the application of lower versus higher PEEP in patients with ALI/ ARDS. ${ }^{11,77-81}$ Of these, only 2 reported a significant mortality reduction with higher PEEP. ${ }^{11,81}$ In both of the studies, however, 2 interventions were applied. That is, a higher PEEP was combined with a lower $\mathrm{V}_{\mathrm{T}}$. Therefore, it is unknown whether the mortality benefit was related to the higher PEEP, lower $\mathrm{V}_{\mathrm{T}}$, or a combined effect of the 2 interventions.

In an ARDS Network study, Brower et al ${ }^{77}$ randomly assigned 549 patients with ALI/ARDS to receive either lower or higher PEEP. All patients received volume and pressure limitation according to the original ARDS Network study. ${ }^{13}$ The PEEP was selected according to different tables of predetermined combinations of PEEP and $\mathrm{F}_{\mathrm{IO}_{2}}$, selected to maintain $\mathrm{P}_{\mathrm{aO}}$ in the range of $55-80 \mathrm{~mm} \mathrm{Hg}$ or $\mathrm{S}_{\mathrm{pO}_{2}}$ in the range of $88-95 \%$ (Table 3). The mean $\pm \mathrm{SD}$ PEEP on days 1 through 4 were $8.3 \pm 3.2 \mathrm{~cm} \mathrm{H}_{2} \mathrm{O}$ in the lower-PEEP group and $13.2 \pm 3.5 \mathrm{~cm} \mathrm{H}_{2} \mathrm{O}$ in the higherPEEP group. Not surprising, the $\mathrm{P}_{\mathrm{aO}} / \mathrm{F}_{\mathrm{IO}_{2}}$ was significantly greater in the higher-PEEP group $(P<.01)$. The rates of death before hospital discharge were $24.9 \%$ and $27.5 \%$, respectively $(P=.48)$. There were $14.5 \pm 10.4$ ventilator free days in the lower-PEEP group and $13.8 \pm 10.6$ ventilator free days in the higher-PEEP group $(P=.50)$. The data and safety monitoring board stopped the study at the second interim analysis, after 549 patients had been enrolled, on the basis of futility. The authors concluded that, in patients with ALI/ARDS who receive mechanical ventilation with a $\mathrm{V}_{\mathrm{T}}$ goal of $6 \mathrm{~mL} / \mathrm{kg}$ of IBW and a $\mathrm{P}_{\text {plat }} \leq 30 \mathrm{~cm} \mathrm{H}_{2} \mathrm{O}$, clinical outcomes are similar whether lower or higher PEEP is used.

Meade et al78 reported a study to compare a low- $\mathrm{V}_{\mathrm{T}}$ ventilation strategy with an experimental strategy designed as an open-lung approach, which combines low $\mathrm{V}_{\mathrm{T}}$, lungrecruitment maneuvers, and high PEEP. This was a randomized controlled trial with concealed allocation and blinded data analysis conducted in 30 intensive care units in Canada, Australia, and Saudi Arabia. The study enrolled 983 patients with ALI and $\mathrm{P}_{\mathrm{aO}} / \mathrm{F}_{\mathrm{IO}_{2}} \leq 250 \mathrm{~mm} \mathrm{Hg} ; 85 \%$ 
of the subjects met the criteria for ARDS at enrollment. The control strategy included a target $\mathrm{V}_{\mathrm{T}}$ of $6 \mathrm{~mL} / \mathrm{kg}$ IBW, $\mathrm{P}_{\text {plat }} \leq 30 \mathrm{~cm} \mathrm{H} \mathrm{H}_{2} \mathrm{O}$, and a conventional PEEP level $(n=508)$. The open-lung strategy included target $\mathrm{V}_{\mathrm{T}}$ of $6 \mathrm{~mL} / \mathrm{kg} \mathrm{IBW}, \mathrm{P}_{\text {plat }} \leq 40 \mathrm{~cm} \mathrm{H}_{2} \mathrm{O}$, recruitment maneuvers, and higher PEEP $(n=475)$. The mean PEEP was $14.6 \pm 3.4 \mathrm{~cm} \mathrm{H} \mathrm{H}_{2} \mathrm{O}$ in the open-lung group and $9.8 \pm 2.7 \mathrm{~cm} \mathrm{H}_{2} \mathrm{O}$ in the control group during the first 72 hours $(P<.001)$. All-cause hospital mortality rates were $36.4 \%$ and $40.4 \%$, respectively $(P=.19)$. Barotrauma rates were $11.2 \%$ and $9.1 \%(P=.33)$. The openlung group had lower rates of refractory hypoxemia $(4.6 \%$ vs $10.2 \%, P=.01)$, death with refractory hypoxemia $(4.2 \%$ vs $8.9 \%, P=.03)$, and use of rescue therapies $(5.1 \%$ vs $9.3 \%, P=.045)$. The authors concluded that, for patients with ALI/ARDS, a ventilation strategy designed to recruit and open the lungs resulted in no significant difference in hospital mortality, compared with an established low- $\mathrm{V}_{\mathrm{T}}$ ventilation strategy. This open-lung strategy did appear to improve secondary end points related to hypoxemia and use of rescue therapies.

Mercat et al ${ }^{79}$ designed a study to compare the effect on outcome of a strategy for setting PEEP aimed at increasing alveolar recruitment while limiting hyperinflation to one aimed at minimizing alveolar distention in patients with ALI. This was a multicenter randomized controlled trial of 767 adults conducted in 37 intensive care units in France. The $\mathrm{V}_{\mathrm{T}}$ was set at $6 \mathrm{~mL} / \mathrm{kg}$ IBW in both strategies. Patients were randomly assigned to a moderate PEEP strategy of $5-9 \mathrm{~cm} \mathrm{H}_{2} \mathrm{O}(n=382)$ or to a PEEP set to reach a $\mathrm{P}_{\text {plat }}$ of $28-30 \mathrm{~cm} \mathrm{H}_{2} \mathrm{O}(n=385)$. The 28-day mortality rate in the minimal-distention group was $31.2 \%$ versus $27.8 \%$ in the increased-recruitment group $(P=.31)$. The hospital mortality rate in the minimal-distention group was $39.0 \%$ versus $35.4 \%$ in the increased-recruitment group $(P=.30)$. The increased-recruitment group, compared with the minimal-distention group, had a higher median number of ventilator-free days (7 d, interquartile range [IQR] 0-19 d vs $3 \mathrm{~d}$, IQR $0-17, P=.04$ ) and organ-failure-free days (6 d, IQR $0-18$ vs $2 \mathrm{~d}$, IQR $0-16, P=.04$ ). This strategy also was associated with higher compliance values, better oxygenation, less use of adjunctive therapies, and larger fluid requirements. The authors concluded that a strategy for setting PEEP aimed at increasing alveolar recruitment while limiting hyperinflation did not significantly reduce mortality. However, it did improve lung function and reduced the duration of mechanical ventilation and the duration of organ failure.

The reason why these 3 trials were negative with respect to a survival benefit has been the source of much speculation and debate. Perhaps a higher level of PEEP in patients with ALI/ARDS is not effective. Perhaps the methods used to set PEEP were not the correct approaches. Perhaps higher PEEP is not effective in unselected patients with ALI/ARDS, but might be effective in patients with ARDS but not ALI, or in patients with a higher potential for recruitment. Or perhaps these studies, although relatively large, were underpowered to show a difference in outcome. ${ }^{82}$

\section{PEEP and Potential for Recruitment}

An important issue with the use of higher PEEP is the associated increase in $\mathrm{P}_{\text {plat }}{ }^{43}$ This is more likely to occur when higher PEEP is added to patients who have nonrecruitable lung regions. Patients who have recruitable lungs have proportionally less increase in $\mathrm{P}_{\text {plat }}$ when PEEP is raised, and such patients may benefit from PEEP with less risk of over-distention. It is likely that the trials of higher versus lower PEEP ${ }^{77-79}$ enrolled patients who had both a lower and a greater potential for alveolar recruitment.

In 68 patients with ALI/ARDS, Gattinoni et al ${ }^{83}$ evaluated the relationship between the percentage of potentially recruitable lung and the clinical and physiologic effects of PEEP. Patients underwent whole-lung CT at airway pressures of 5,15 , and $45 \mathrm{~cm} \mathrm{H}_{2} \mathrm{O}$. The potential for recruitment was defined as the proportion of lung tissue in which aeration was restored at airway pressures between 5 and $45 \mathrm{~cm} \mathrm{H}_{2} \mathrm{O}$. They found that the percentage of potentially recruitable lung ranged widely in these patients, with a mean of $13 \pm 11 \%$ of the lung weight. An average of $24 \%$ of the lung could not be recruited. Patients with a higher percentage of potentially recruitable lung, greater than the median value of $9 \%$, had greater total lung weights, lower $\mathrm{P}_{\mathrm{aO}} / \mathrm{F}_{\mathrm{IO}_{2}}$ and respiratory-system compliance, higher dead space, and higher mortality. CT was better than physiologic variables for predicting the amount of recruitable lung, Clinically relevant changes in physiologic markers with higher PEEP, such as reduced physiologic dead space (or a decrease in $\mathrm{P}_{\mathrm{aCO}}$ at a fixed minute ventilation) or an increase in respiratory-system compliance, may be helpful indicators of lung recruitability.

To investigate how lung recruitability influences alveolar strain and cyclical opening and closing after the application of high PEEP, Caironi et al $^{84}$ analyzed data from the 68 patients with ALI/ARDS in the previously described paper by Gattinoni. ${ }^{83}$ Alveolar strain and opening and closing lung tissue were computed at 5 and $15 \mathrm{~cm} \mathrm{H}_{2} \mathrm{O}$ PEEP. In patients with a higher percentage of potentially recruitable alveoli, the increase in PEEP reduced the amount of opening and closing lung tissue $(P<.001)$. However, no differences were observed in patients with a lower percentage of potentially recruitable alveoli. Alveolar strain similarly increased in the 2 groups. Opening and closing lung tissue was distributed mainly in the dependent and hilar lung regions, and it was an independent risk factor for death. The authors concluded that, in patients with higher alveolar recruitability, the beneficial impact of reducing 


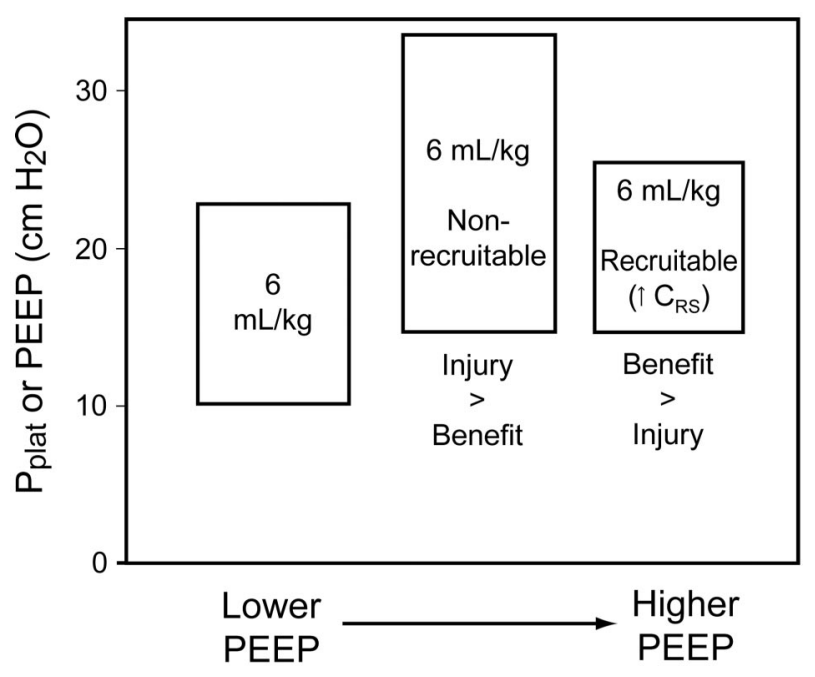

Fig. 3. Potential effects of an increase in PEEP. If the potential for recruitment is low, an increase in PEEP results in a large increase in plateau pressure $\left(P_{\text {plat }}\right)$ (increased driving pressure), to an unsafe level. In this case, the potential harm from over-distention probably outweighs any benefit resulting from increased alveolar recruitment. If the potential for recruitment is high, an increase in PEEP results in little increase in $\mathrm{P}_{\text {plat }}$. In this case, the potential benefit of increased PEEP probably outweighs the harm due to the small increase in $P_{\text {plat }}$.

cyclical alveolar opening and closing by increasing PEEP prevails over the effects of increasing alveolar strain.

Because the effects of high PEEP depend on lung recruitability, which varies widely among patients with ARDS, increasing PEEP may lead to alveolar over-distention (harm), or to less cyclical alveolar opening and closing (benefit). This is illustrated in Figure 3. If the increase in PEEP is greater than the increase in $\mathrm{P}_{\text {plat }}$, presumably alveolar recruitment has occurred, the respiratory system is improved, and the benefit of higher PEEP may be greater than the potential harm of the small increase in $\mathrm{P}_{\text {plat }}$. On the other hand, if the increase in $\mathrm{P}_{\text {plat }}$ is greater than the increase in PEEP, particularly if the resulting $\mathrm{P}_{\text {plat }}$ is $>30 \mathrm{~cm} \mathrm{H}_{2} \mathrm{O}$, then it can be argued that the harm of over-distention is greater than the benefit of alveolar recruitment with PEEP. Because the 3 PEEP studies probably enrolled some patients with higher potential for recruitment and other patients with a lower potential for recruitment, this may explain the negative results.

A higher PEEP potentially increases the risks of hemodynamic compromise and barotrauma. Pneumothorax rate does not appear to be greater in patients receiving higher PEEP. ${ }^{85}$ The risk of complications is probably related to over-distention rather than PEEP per se.

\section{The Meta-Analyses}

The value of a meta-analysis is that, by pooling data from several studies, statistical power is improved. Thus, results from smaller negative studies might prove positive when combined in a meta-analysis. There are 5 metaanalyses published on the topic of higher versus lower PEEP in patients with ALI/ARDS (Table 4). ${ }^{85-89}$ Of these,

Table 4. Meta-analyses of Studies That Compared Higher Versus Lower PEEP

\begin{tabular}{|c|c|c|c|}
\hline Meta-analysis & Studies Included & Principal Finding & Comments \\
\hline $\mathrm{Oba}^{87}$ & $\begin{array}{l}\text { Amato }^{11} \\
\text { Brower }^{77} \\
\text { Meade }^{78} \\
\text { Mercat }^{79} \\
\text { Villar }^{81}\end{array}$ & $\begin{array}{l}\text { Lower hospital mortality with higher PEEP } \\
\quad(\text { RR } 0.89,95 \% \text { CI } 0.80-0.99, P=.03 \text { ) }\end{array}$ & $\begin{array}{l}\text { Analysis included studies that used } 2 \\
\text { simultaneous interventions: higher } \\
\text { PEEP with lower } \mathrm{V}_{\mathrm{T}} \text { vs lower PEEP } \\
\text { with higher } \mathrm{V}_{\mathrm{T}}\end{array}$ \\
\hline Putensen $^{89}$ & $\begin{array}{l}\text { Brower }^{77} \\
\text { Meade }^{78} \\
\text { Mercat }^{79}\end{array}$ & $\begin{array}{l}\text { Higher PEEP did not reduce hospital mortality (OR } \\
\quad 0.86,95 \% \text { CI, } 0.72-1.02, P=.08 \text { ) }\end{array}$ & $\begin{array}{l}\text { Lower } \mathrm{V}_{\mathrm{T}} \text { reduced hospital mortality } \\
(\mathrm{OR} 0.75,95 \% \text { CI } 0.58-0.96, \\
P=.02) \text { compared to higher } \mathrm{V}_{\mathrm{T}} \text { at } \\
\text { similar PEEP }\end{array}$ \\
\hline Phoenix $^{88}$ & $\begin{array}{l}\text { Brower }^{77} \\
\text { Meade }^{78} \\
\text { Mercat }^{79}\end{array}$ & $\begin{array}{l}\text { Higher PEEP did not reduce hospital mortality in the } \\
3 \text { trials that used } 2 \text { PEEP levels, but } \mathrm{V}_{\mathrm{T}} \text { was held } \\
\text { constant (RR } 0.90,95 \% \text { CI } 0.72-1.02, P=.077 \text { ) }\end{array}$ & $\begin{array}{l}\text { Concluded that high PEEP may have a } \\
\text { clinically relevant mortality benefit }\end{array}$ \\
\hline Briel $^{86}$ & $\begin{array}{l}\text { Brower }^{77} \\
\text { Meade }^{78} \\
\text { Mercat }^{79}\end{array}$ & $\begin{array}{l}\text { Patients with ARDS benefited from higher PEEP } \\
\text { (RR 0.90, 95\% CI } 0.81-1.00, P=.049 \text { ) } \\
\text { Patients without ARDS did not benefit from higher } \\
\text { PEEP (RR } 1.37,95 \% \text { CI } 0.98-1.92, P=.07 \text { ) }\end{array}$ & $\begin{array}{l}\text { Used patient-level data rather than } \\
\text { pooled results }\end{array}$ \\
\hline Dasenbrook $^{85}$ & $\begin{array}{l}\text { Brower }^{77} \\
\text { Meade }^{78} \\
\text { Mercat }^{79} \\
\text { Talmor }^{80}\end{array}$ & $\begin{array}{l}\text { No significant difference in 28-day mortality } \\
\text { (RR 0.90, 95\% CI 0.79-1.02) or in-hospital } \\
\text { mortality (RR 0.94, 95\% CI 0.84-1.05) for higher } \\
\text { versus lower PEEP }\end{array}$ & $\begin{array}{l}\text { Pneumothorax rate not increased with } \\
\text { higher PEEP }\end{array}$ \\
\hline $\begin{array}{l}\mathrm{RR}=\text { relative risk } \\
\mathrm{OR}=\text { odds ratio } \\
\text { (Adapted from } \mathrm{Ref}\end{array}$ & & & \\
\hline
\end{tabular}


Table 5. Methods for Selecting PEEP

\section{Table}

Maximal PEEP while avoiding overdistention

Gas exchange

Compliance

Stress index

Esophageal pressure ${ }^{8}$

Pressure-volume curve

Imaging
Use a table of $\mathrm{F}_{\mathrm{IO}_{2}}$ and PEEP combinations to achieve $\mathrm{P}_{\mathrm{aO}_{2}}$ or $\mathrm{S}_{\mathrm{pO}_{2}}$ in a target range Use highest PEEP with plateau pressure $<30 \mathrm{~cm} \mathrm{H}_{2} \mathrm{O}$

Lowest shunt (highest $\mathrm{P}_{\mathrm{aO}}$ ), lowest dead space (lowest $\mathrm{P}_{\mathrm{aCO}}$ ), best oxygen delivery $\left(\mathrm{C}_{\mathrm{aO}_{2}} \times\right.$ cardiac output $)$

Use the PEEP that results in the highest respiratory-system compliance

Observe the pressure-time curve during constant-flow inhalation for signs of tidal recruitment and over-distention

Estimate the intra-pleural pressure with an esophageal-balloon measurement of esophageal pressure, then determine the optimal PEEP

Set PEEP slightly higher than the lower inflection point

Computed tomography, electrical impedance tomography, ultrasound
4 found no effect on mortality from higher PEEP, compared with moderate PEEP, in unselected patients with ALI/ARDS. ${ }^{85,87-89}$

The meta-analysis by Briel et al ${ }^{86}$ is of particular interest. Data from 2,299 individual patients in 3 trials were analyzed, using uniform outcome definitions. The mortality rate was $32.9 \%$ for patients assigned to treatment with higher PEEP, and $35.2 \%$ for patients assigned to lower PEEP (adjusted relative risk 0.94, 95\% CI 0.86-1.04, $P=.25)$. However, treatment effects varied with the presence or absence of ARDS $\left(\mathrm{P}_{\mathrm{aO}_{2}} / \mathrm{F}_{\mathrm{IO}_{2}} \leq 200 \mathrm{~mm} \mathrm{Hg}\right)$. In patients with ARDS the mortality was $34.1 \%$ in the higher-PEEP group and $39.1 \%$ in the lower-PEEP group (adjusted relative risk $0.90,95 \% \mathrm{CI} 0.81-1.00, P=.049)$. In patients without ARDS the mortality was $27.2 \%$ in the higher-PEEP group and $19.4 \%$ in the lower-PEEP group (adjusted relative risk 1.37, 95\% CI 0.98-1.92, $P=.07$ ). The results of this meta-analysis suggest that treatment with higher versus lower PEEP was associated with improved survival among the subgroup of patients with ARDS $\left(\mathrm{P}_{\mathrm{aO}_{2}} / \mathrm{F}_{\mathrm{IO}_{2}} \leq 200 \mathrm{~mm} \mathrm{Hg}\right)$. Interestingly, there was a trend toward worse outcomes with higher PEEP in the subgroup with ALI $\left(\mathrm{P}_{\mathrm{aO}_{2}} / \mathrm{F}_{\mathrm{IO}_{2}}>200 \mathrm{~mm} \mathrm{Hg}\right)$.

\section{Approaches to Setting PEEP}

Zero PEEP is probably harmful during mechanical ventilation of patients with ALI/ARDS. ${ }^{76}$ Higher PEEP is probably better in patients with ARDS, and moderate PEEP may be better for patients with ALI. The challenge at the bedside is to select the PEEP that is appropriate for the individual patient, and a number of approaches have been described in the literature (Table 5).

In the ARDS Network studies ${ }^{13,77}$ and the study by Meade et al, ${ }^{78}$ PEEP was individually titrated according to a table, with combinations of PEEP and $\mathrm{F}_{\mathrm{IO}_{2}}$ selected for a target arterial oxygenation (see Table 3). These tables have been widely criticized as arbitrary and not fitted to the lung mechanics of an individual patient. Despite the criticism of these tables, they have been used successfully in all of the

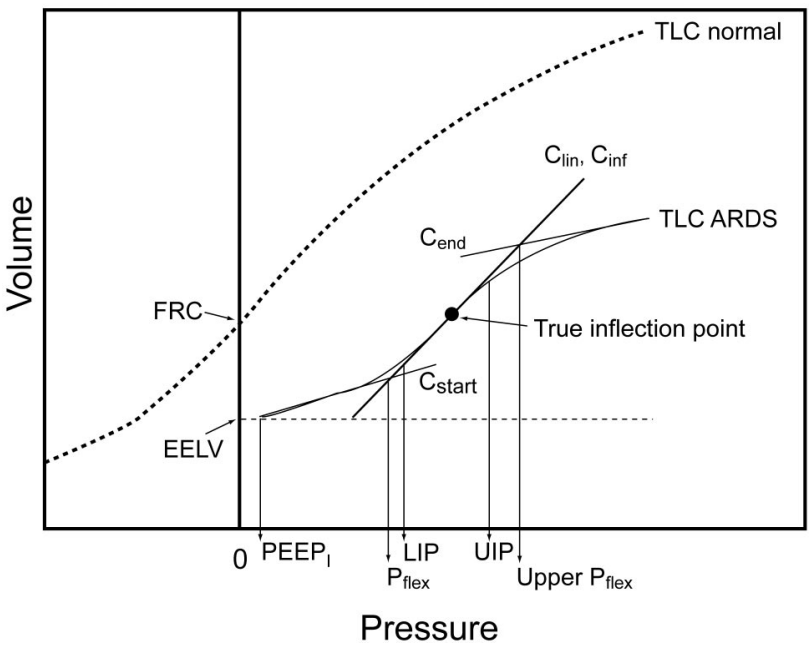

Fig. 4. The pressure-volume curve of a normal subject (dashed curve) and a patient with acute respiratory distress syndrome (ARDS) (solid curve). The pressure-volume curve is shifted downwards on the volume axis and has a reduced total lung capacity (TLC). The sigmoid shape of the curve is much more evident in ARDS. Note the small amount of pressure at the start of the ARDS pressure-volume curve, indicating a small amount of intrinsic PEEP $\left(P E E P_{1}\right)$ at end-expiratory lung volume (EELV). Some investigators divide the curve into linear segments: $\mathrm{C}_{\text {start }}, \mathrm{C}_{\text {inf }}$ or $\mathrm{C}_{\text {lin }}$, and $\mathrm{C}_{\text {end }}$ (thin lines, explained below). Using these segments, the upper and lower $\mathrm{P}_{\text {flex }}$ (the pressure at the intersection of 2 lines: a low-compliance region at low lung volumes $\left[\mathrm{C}_{\text {start }}\right]$ and a higher-compliance region at higher lung volumes $\left[\mathrm{C}_{\text {inf }}\right]$ ) were defined by the intersection of these lines. The lower inflection point (LIP) and upper inflection point (UIP) are defined by where the curve first begins to deviate from the line $C_{\text {lin }}$. Mathematically these are not inflection points; the true inflection point (where concavity changes direction) is marked by the solid dot. (Adapted from Reference 94.)

trials conducted by the ARDS Network and thus have high face validity. ${ }^{16}$ But because these tables do not select PEEP based on potential for alveolar recruitment, their use might lead to over-distention in patients who have less potential for recruitment. ${ }^{90-92}$

The method used by Mercat et al79 is simple and attractive. They adjusted PEEP based on airway pressure, and PEEP was set as high as possible without increasing the 

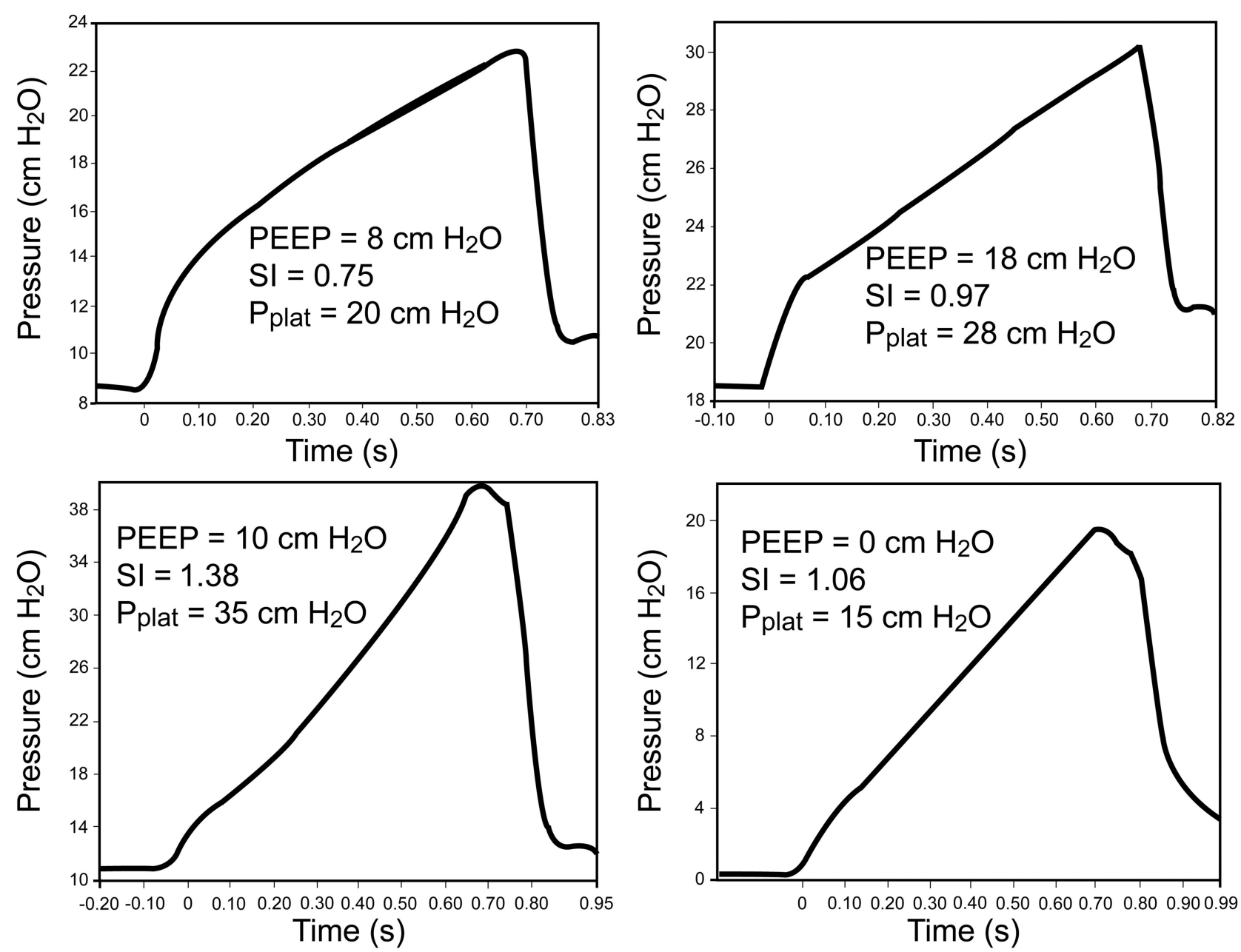

Fig. 5. Top: Stress index in a patient early in the course of acute respiratory distress syndrome (ARDS) secondary to H1N1 infection. In this case the stress index improved as PEEP was increased. Bottom: Stress index (SI) in a patient late in the course of ARDS. In this case the stress index improved as PEEP was decreased.

$\mathrm{P}_{\text {plat }}$ above $28-30 \mathrm{~cm} \mathrm{H}_{2} \mathrm{O}$. PEEP was individually titrated based on $\mathrm{P}_{\text {plat, }}$, regardless of its effect on oxygenation. Using this approach, higher PEEP will probably be set when there is much potential for recruitment, because there will be less increase in $\mathrm{P}_{\text {plat }}$ when the application of PEEP increases alveolar recruitment. On the other hand, if there is less potential for recruitment, the $\mathrm{P}_{\text {plat }}$ limit will be reached quickly when the PEEP is increased. ${ }^{79}$

In a classic paper published in 1975 , Suter et $\mathrm{al}^{93}$ studied 15 normovolemic patients who required mechanical ventilation for acute pulmonary failure. The PEEP that resulted in the maximum oxygen delivery and the lowest dead-space fraction also resulted in the greatest respiratory-system compliance. The optimal PEEP ranged between 0 and $15 \mathrm{~cm} \mathrm{H}_{2} \mathrm{O}$. Mixed venous $\mathrm{P}_{\mathrm{O}_{2}}$ increased between 0 PEEP and the PEEP that resulted in maximum oxygen delivery, but then decreased at higher PEEP. The authors concluded that respiratory-system compliance can be used to determine the optimal PEEP. Because compliance $=\mathrm{V}_{\mathrm{T}}$
$/\left(\mathrm{P}_{\text {plat }}-\mathrm{PEEP}\right)$, the optimal PEEP is that which results in the lowest driving pressure $\left(\mathrm{P}_{\text {plat }}-\mathrm{PEEP}\right)$ if $\mathrm{V}_{\mathrm{T}}$ is kept constant. What is most attractive about this approach is that it is easy to evaluate at the bedside.

The pressure-volume (PV) curve has been used to select optimal PEEP (Fig. 4). ${ }^{94}$ With this approach, the relationship between volume and pressure as the lungs are inflated or deflated is evaluated. By assessing the shape of this relationship, the pressure at which alveoli are recruited or derecruited is identified. This approach has been used in several randomized controlled trials of lung-protective ventilation. ${ }^{11,81}$ Measurement of the PV curve, however, requires sedation and often paralysis, because even minimal patient effort may confound measurements of inflection points. There can be considerable inter-observer variability in interpreting PV curves. ${ }^{95}$ Separation of the effect of the chest wall from the effect of the lungs on the PV curve is not possible without measuring esophageal pressure. ${ }^{96-98}$ The shape of the PV curve may be affected by the starting 
pressure (ie, PEEP). ${ }^{99,100}$ Finally, it is now accepted that recruitment may occur throughout the entire inflation PV curve. As such, attention has focused more recently on the deflation limb of the PV curve, where the upper inflection point may represent the beginning of derecruitment. ${ }^{101}$ The traditional method for determining the PV curve is to use a calibrated syringe, with measures of pressure for each step change in volume. Dynamic PV curves plotted on the ventilator screen are potentially useful only if the lungs are inflated with a constant slow flow. ${ }^{94}$ Dynamic PV curves measured during PCV or descending-ramp VCV are not useful. Although automated procedures integral to the ventilator system have made it easier to construct a PV curve, ${ }^{102}$ more evidence is needed before the PV curve can be recommended for routine use to determine optimal PEEP.

The stress index has been proposed to assess the level of PEEP to maximize recruitment yet avoid overdistention. ${ }^{91,103}$ This approach uses the shape of the pressure-time curve during constant-flow VCV. A linear increase in pressure suggests adequate recruitment without over-distention. If compliance is worsening as the lungs are inflated (upward concavity, stress index $>1$ ), this suggests over-distention and the recommendation is to decrease PEEP. If the compliance is improving as the lungs are inflated (downward concavity, stress index $<1$ ), this suggests tidal recruitment and potential for additional recruitment, and thus a recommendation to increase PEEP. Examples of changes in stress index in patients with ARDS are shown in Figure 5.

Particularly in patients with extrapulmonary ARDS, the chest-wall compliance may be reduced. ${ }^{104}$ Chest-wall compliance is reduced with abdominal-compartment syndrome, chest-wall edema, pleural effusion, or obesity. ${ }^{105,106}$ This can result in an increase in pleural pressure and, if pleural pressure is high relative to alveolar pressure, there may be potential for alveolar collapse (Fig. 6). In that case it is desirable to keep PEEP greater than pleural pressure. The use of an esophageal balloon to assess intra-pleural pressure has been advocated to allow more precise setting of PEEP (Fig. 7). ${ }^{80,106-108}$ Unfortunately, artifacts in esophageal pressure, especially in supine critically ill patients, make it difficult to measure absolute pleural pressure accurately. ${ }^{109}$ In patients with abdominal-compartment syndrome, bladder pressure may be useful to assess intraabdominal pressure, the potential collapsing effect on the lungs, and the amount of PEEP necessary to counterbalance this effect. ${ }^{105,107}$

Some advocate opening the lung with recruitment maneuvers, with subsequent stepwise reduction of PEEP until evidence of derecruitment (eg, respiratory-system compliance change) is identified on the deflation limb of the PV curve, with a decremental, rather than an incremental, PEEP trial. ${ }^{110,111}$ Using this approach, PEEP is set $\geq 20 \mathrm{~cm} \mathrm{H}_{2} \mathrm{O}$ and then decreased to identify the level

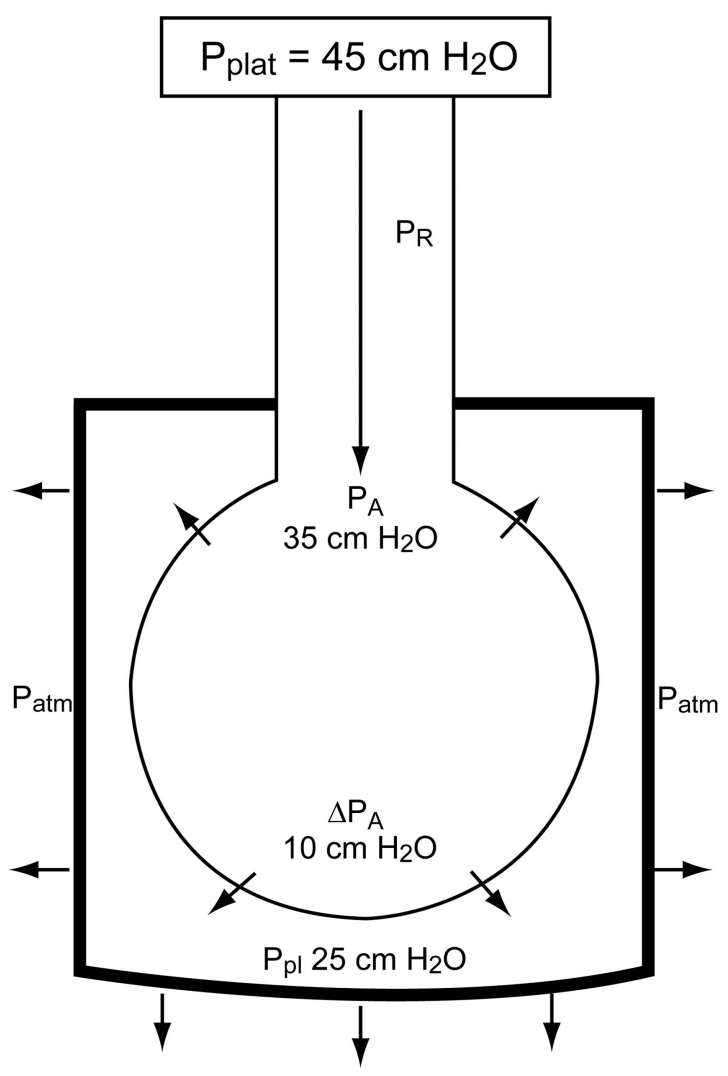

Fig. 6. Effect of a stiff chest wall on transpulmonary pressure. In this example, although the plateau pressure $\left(\mathrm{P}_{\text {plat }}\right)$ is $35 \mathrm{~cm} \mathrm{H} \mathrm{H}_{2} \mathrm{O}$, the distending pressure across the alveolus is only $10 \mathrm{~cm} \mathrm{H}_{2} \mathrm{O}$ because the pleural pressure is $25 \mathrm{~cm} \mathrm{H}_{2} \mathrm{O}$. $\mathrm{P}_{\mathrm{R}}=$ pressure drop due to airways resistance. $\mathrm{P}_{\mathrm{A}}=$ alveolar pressure. $\Delta \mathrm{P}_{\mathrm{A}}=$ transalveolar pressure. $\mathrm{P}_{\mathrm{atm}}=$ atmospheric pressure. $\mathrm{P}_{\mathrm{pl}}=$ pleural pressure.

that produces the best $\mathrm{P}_{\mathrm{aO}_{2}}$ and compliance. However, a recent study was unable to show differences in patient outcomes when setting PEEP with a table was compared to a method that used recruitment maneuvers and decremental PEEP. ${ }^{112}$

Dead-space measurements may be helpful to determine the optimal PEEP. ${ }^{93}$ As PEEP is increased, the ratio of dead space to $\mathrm{V}_{\mathrm{T}}\left(\mathrm{V}_{\mathrm{D}} / \mathrm{V}_{\mathrm{T}}\right)$ should decrease as alveoli are recruited. If PEEP results in alveolar over-distention, however, $\mathrm{V}_{\mathrm{D}} / \mathrm{V}_{\mathrm{T}}$ should increase. It should be possible, however, to assess these effects by evaluating $\mathrm{P}_{\mathrm{aCO}}$ with fixed minute ventilation; a decrease in $\mathrm{P}_{\mathrm{aCO}}$ is consistent with a lower $\mathrm{V}_{\mathrm{D}} / \mathrm{V}_{\mathrm{T}}$, and vice versa. Methods are now available to measure functional residual capacity at the bedside in patients with ARDS. ${ }^{113,114}$ However, it is difficult to know whether an increase in lung volume with an increase in PEEP is due to alveolar recruitment or over-distention.

Imaging techniques have been used to evaluate PEEP settings. But CT is not practical. Ultrasound ${ }^{115}$ and electrical impedance tomography ${ }^{116,117}$ need additional validation. One 

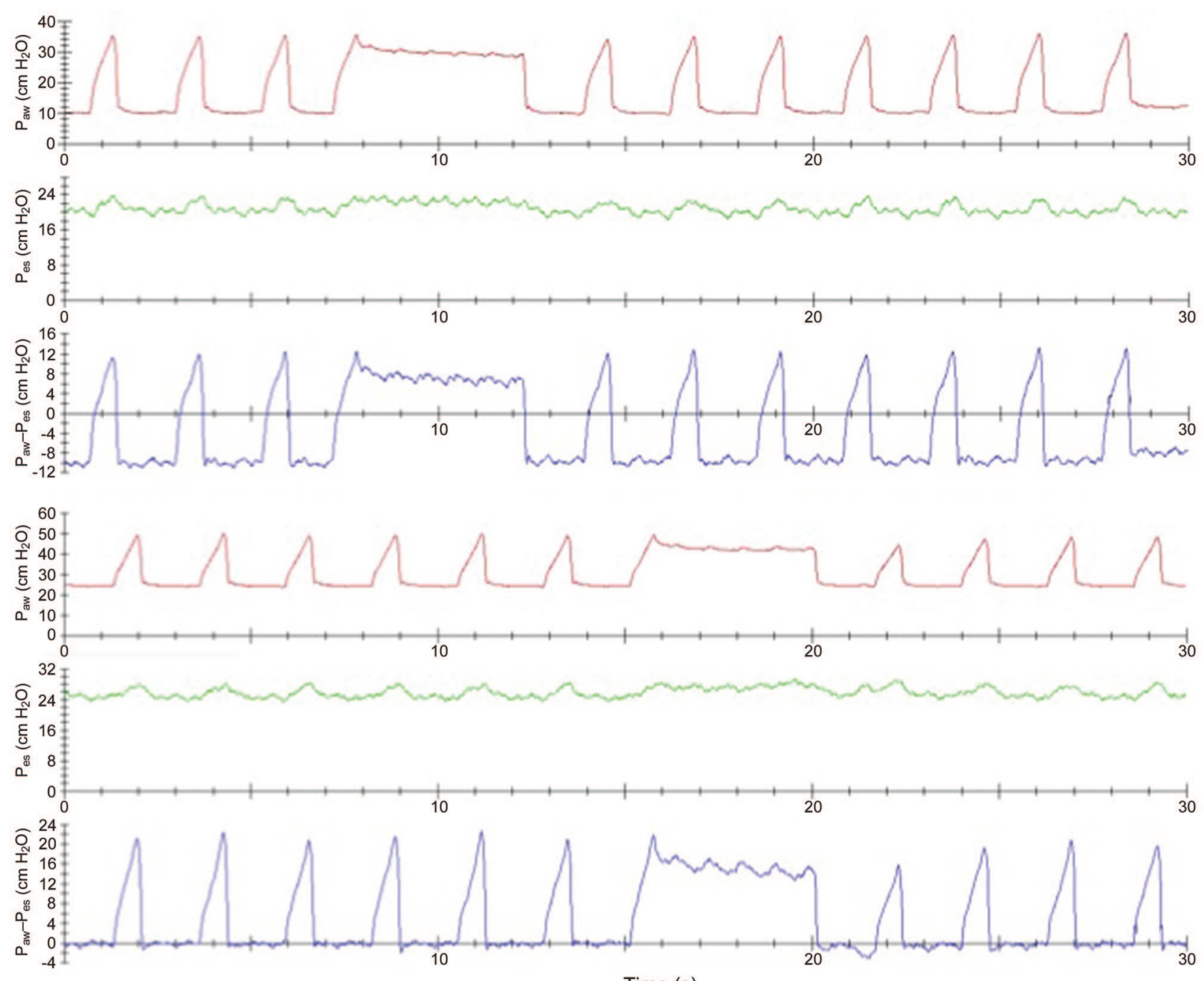

Time (s)

Fig. 7. Example of PEEP titration in a patient with morbid obesity. Top: Esophageal pressure $\left(\mathrm{P}_{\text {es }}\right)$, as a surrogate for pleural pressure, is greater than the setting on PEEP. Bottom: PEEP setting is increased so that the collapsing effect of the intrapleural pressure is counterbalanced. Note that, despite the plateau pressure of $40 \mathrm{~cm} \mathrm{H} \mathrm{H}_{2} \mathrm{O}$, the alveolar distending pressure is only $14 \mathrm{~cm} \mathrm{H}_{2} \mathrm{O}$.

issue with these imaging techniques is that it can be difficult to differentiate recruitment from over-distention.

It is unclear whether any one of the methods to set PEEP is superior to the others. Use of higher PEEP, when compared to use of moderate PEEP, does not lead to lower mortality in groups of unselected patients with ALI/ARDS. It is becoming increasingly recognized that different PEEP strategies may be needed for different types of ARDS; for example, when the lungs are highly recruitable versus poorly recruitable. Unfortunately, given the complexity of conducting clinical trials in patients with ALI/ARDS, it is unlikely that high-level studies of higher versus moderate PEEP will be conducted in patients selected on the basis of alveolar recruitment potential.

PEEP is good for patients with ALI/ARDS. The debate is not whether PEEP should be used, but rather how much
PEEP should be used. Second, the available evidence suggests that a modest PEEP may be more appropriate for ALI $\left(\mathrm{P}_{\mathrm{aO}_{2}} / \mathrm{F}_{\mathrm{IO}_{2}}>200 \mathrm{~mm} \mathrm{Hg}\right)$, whereas higher PEEP should be used for ARDS $\left(\mathrm{P}_{\mathrm{aO}_{2}} / \mathrm{F}_{\mathrm{IO}_{2}} \leq 200 \mathrm{~mm} \mathrm{Hg}\right)$. Higher PEEP should be reserved for patients in whom alveolar recruitment can be demonstrated. Increasing PEEP while driving up the $\mathrm{P}_{\text {plat }}$ to a harmful level makes no sense.

\section{Stress and Strain}

The primary determinants of VILI are stress and strain. ${ }^{118}$ Stress is the internal distribution of the counterforce per unit of area that balances and reacts to an external load. The associated deformation of the structure is strain, defined as the change in size or shape in reference to the initial status. The clinical equivalent of stress is transpul- 
Table 6. Ventilator Settings for ALI/ARDS

1. Choose ventilation mode

Although any mode may be used, note that the ARDS Network study was performed with volume controlled continuous mandatory ventilation. Regardless of the mode, choose settings that ensure both the volume and pressure limitations. An important caveat is that $\mathrm{P}_{\text {plat }}$ may not reflect transpulmonary pressure in pressure-targeted modes (pressure controlled ventilation, pressure support ventilation, adaptive pressure control) if the patient is making active inspiratory efforts that lower the pleural pressure.

2. Calculate ideal body weight (IBW)

Males: IBW $(\mathrm{kg})=50.0+2.3[$ height (inches)-60]

Females: IBW $(\mathrm{kg})=45.5+2.3$ [height (inches)-60]

3. Choose $\mathrm{V}_{\mathrm{T}}$ goal of $6 \mathrm{~mL} / \mathrm{kg}$ predicted body weight

4. Set PEEP to $\geq 8 \mathrm{~cm} \mathrm{H}_{2} \mathrm{O}$

5. Measure and record $P_{\text {plat }}$ at least every 4 hours and after any changes in $V_{T}$ or PEEP: If $\mathrm{P}_{\text {plat }}>30 \mathrm{~cm} \mathrm{H}_{2} \mathrm{O}$, reduce $\mathrm{V}_{\mathrm{T}}$ to $5 \mathrm{~mL} / \mathrm{kg} \mathrm{IBW}$, and then to $4 \mathrm{~mL} / \mathrm{kg} \mathrm{IBW}$, if necessary to decrease $\mathrm{P}_{\text {plat }}$ to $\leq 30 \mathrm{~cm} \mathrm{H}_{2} \mathrm{O}$.

If $\mathrm{V}_{\mathrm{T}}<6 \mathrm{~mL} / \mathrm{kg} \mathrm{IBW}$ and $\mathrm{P}_{\text {plat }}<25 \mathrm{~cm} \mathrm{H}_{2} \mathrm{O}$, increase $\mathrm{V}_{\mathrm{T}}$ by $1 \mathrm{~mL} / \mathrm{kg} \mathrm{IBW}$ to a maximum of $6 \mathrm{~mL} / \mathrm{kg}$.

6. Adjust respiratory rate or $\mathrm{V}_{\mathrm{T}}$ according to $\mathrm{pH}$ goals:

If $\mathrm{pH}<7.30$, consider increasing the respiratory rate to as high as 35 breaths/min while monitoring for development of auto-PEEP.

If $\mathrm{pH}<7.15$ and respiratory rate 35 breaths/min, consider increasing $\mathrm{V}_{\mathrm{T}}$ and suspending the $\mathrm{P}_{\text {plat }}$ limit, depending on patient tolerance of the acidemia.

7. Set inspiratory-expiratory ratio to 1:2. Adjust to avoid auto-PEEP and asynchrony.

8. Address asynchrony

If severe asynchrony, increase $\mathrm{V}_{\mathrm{T}}$ to 7 or $8 \mathrm{~mL} / \mathrm{kg} \mathrm{IBW}$ if $\mathrm{P}_{\text {plat }}$ remains $<30 \mathrm{~cm} \mathrm{H}_{2} \mathrm{O}$.

If $\mathrm{P}_{\text {plat }}>30 \mathrm{~cm} \mathrm{H}_{2} \mathrm{O}$ on 7 or $8 \mathrm{~mL} / \mathrm{kg} \mathrm{IBW}$, revert to lower $\mathrm{V}_{\mathrm{T}}$, consider ventilator adjustments to improve patient synchrony, and consider additional sedation.

9. Set PEEP to maximize alveolar recruitment while avoiding over-distention.

Increase PEEP in increments of 2-3 $\mathrm{cm} \mathrm{H}_{2} \mathrm{O}$, allow 5-10 min of consistent measurements of airway pressure and $\mathrm{V}_{\mathrm{T}}$. Select the PEEP that gives the best compliance (lowest driving pressure).

When PEEP is decreased, lower PEEP by $2-3 \mathrm{~cm} \mathrm{H}_{2} \mathrm{O}$ and allow at least $30 \mathrm{~min}$ of consistent measurements of airway pressure and $\mathrm{V}_{\mathrm{T}}$ to avoid derecruitment.

If reduced chest wall compliance is likely, esophageal pressure measurements may be useful.

10. Adjust $\mathrm{F}_{\mathrm{IO}_{2}}$ to achieve $\mathrm{S}_{\mathrm{pO}_{2}}$ of $88-95 \%\left(\mathrm{P}_{\mathrm{aO}} 55-80 \mathrm{~mm} \mathrm{Hg}\right)$.

11. Avoid ventilator disconnections and manual ventilation; use in-line suction catheter.

$\overline{\mathrm{ALI}}=$ acute lung injury

ARDS $=$ acute respiratory distress syndrome

$\mathrm{P}_{\text {plat }}=$ plateau pressure

$\mathrm{V}_{\mathrm{T}}=$ tidal volume

(Adapted from Reference 43.)

monary pressure $\left(\Delta \mathrm{P}_{\mathrm{L}}\right)$, and the clinical equivalent of strain is the ratio of volume change $(\Delta \mathrm{V})$ to the functional residual capacity (FRC):

$\Delta \mathrm{P}_{\mathrm{L}}($ stress $)=$ specific lung elastance $\times \Delta \mathrm{V} / \mathrm{FRC}($ strain $)$

$\Delta \mathrm{V}$ is the change in lung volume above resting FRC with the addition of PEEP and $\mathrm{V}_{\mathrm{T}}$. Specific lung elastance is relatively constant at about $13.5 \mathrm{~cm} \mathrm{H}_{2} \mathrm{O}$. A harmful threshold of strain is about 2. Thus, the harmful threshold of stress (transpulmonary pressure) is approximately $27 \mathrm{~cm} \mathrm{H}_{2} \mathrm{O}$. The recommended $\mathrm{P}_{\text {plat }}$ below $30 \mathrm{~cm} \mathrm{H}_{2} \mathrm{O}$ is thus reasonable for most patients with ALI/ARDS. However, a higher $\mathrm{P}_{\text {plat }}$ may be safe when transpulmonary pressure is reduced due to an increase in pleural pressure. This makes a case for measurement of esophageal pressure (as a surrogate for pleural pressure) in a patient with a stiff chest wall.
This concept can be illustrated from Figure 7. When the PEEP is set at $24 \mathrm{~cm} \mathrm{H}_{2} \mathrm{O}$, the end-inspiratory transpulmonary pressure (stress) is $14 \mathrm{~cm} \mathrm{H}_{2} \mathrm{O}$. From the equation above, strain is about 1 . In this case, stress at $14 \mathrm{~cm} \mathrm{H}_{2} \mathrm{O}$ and strain at 1 are both in the safe range $\left(<27 \mathrm{~cm} \mathrm{H}_{2} \mathrm{O}\right.$ and $<2$, respectively), despite the $\mathrm{P}_{\text {plat }}$ of $40 \mathrm{~cm} \mathrm{H}_{2} \mathrm{O}$.

\section{Summary}

Lung-protective ventilation strategies are now widely accepted in the management of patients with ALI/ARDS. In most, if not all, cases of ALI/ARDS, conventional ventilation strategies can be used effectively, as described in this paper. A suggested approach is given in Table 6 .

\section{REFERENCES}

1. Slutsky AS. Ventilator-induced lung injury: from barotrauma to biotrauma. Respir Care 2005;50(5):646-659. 


\section{Approaches to Conventional Mechanical Ventilation of the Patient With ARDS}

2. Slutsky AS, Tremblay LN. Multiple system organ failure. Is mechanical ventilation a contributing factor? Am J Respir Crit Care Med 1998;157(6 Pt 1):1721-1725.

3. Tremblay LN, Slutsky AS. Ventilator-induced injury: from barotrauma to biotrauma. Proc Assoc Am Phys 1998;110(6):482-488.

4. Tremblay LN, Slutsky AS. Ventilator-induced lung injury: from the bench to the bedside. Intensive Care Med 2006;32(1):24-33.

5. Ranieri VM, Giunta F, Suter PM, Slutsky AS. Mechanical ventilation as a mediator of multisystem organ failure in acute respiratory distress syndrome. JAMA 2000;284(1):43-44.

6. Ranieri VM, Suter PM, Tortorella C, De Tullio R, Dayer JM, Brienza A, et al. Effect of mechanical ventilation on inflammatory mediators in patients with acute respiratory distress syndrome: a randomized controlled trial. JAMA 1999;282(1):54-61.

7. Dreyfuss D, Saumon G. Ventilator-induced lung injury: lessons from experimental studies. Am J Respir Crit Care Med 1998;157(1): 294-323.

8. Stewart TE, Meade MO, Cook DJ, Granton JT, Hodder RV, Lapinsky SE, et al. Evaluation of a ventilation strategy to prevent barotrauma in patients at high risk for acute respiratory distress syndrome. Pressure- and Volume-Limited Ventilation Strategy Group. N Engl J Med 1998;338(6):355-361.

9. Brochard L, Roudot-Thoraval F, Roupie E, Delclaux C, Chastre J, Fernandez-Mondejar E, et al. Tidal volume reduction for prevention of ventilator-induced lung injury in acute respiratory distress syndrome. The Multicenter Trail Group on Tidal Volume reduction in ARDS. Am J Respir Crit Care Med 1998;158(6):1831-1838.

10. Brower RG, Shanholtz CB, Fessler HE, Shade DM, White P Jr, Wiener CM, et al. Prospective, randomized, controlled clinical trial comparing traditional versus reduced tidal volume ventilation in acute respiratory distress syndrome patients. Crit Care Med 1999; 27(8):1492-1498.

11. Amato MB, Barbas CS, Medeiros DM, Magaldi RB, Schettino GP, Lorenzi-Filho G, et al. Effect of a protective-ventilation strategy on mortality in the acute respiratory distress syndrome. N Engl J Med 1998;338(6):347-354.

12. Kallet RH. What is the legacy of the National Institutes of Health Acute Respiratory Distress Syndrome Network? Respir Care 2009; 54(7):912-924.

13. The Acute Respiratory Distress Syndrome Network. Ventilation with lower tidal volumes as compared with traditional tidal volumes for acute lung injury and the acute respiratory distress syndrome. N Engl J Med 2000;342(18):1301-1308.

14. Steinberg KP, Kacmarek RM. Respiratory controversies in the critical care setting. Should tidal volume be $6 \mathrm{~mL} / \mathrm{kg}$ predicted body weight in virtually all patients with acute respiratory failure? Respir Care 2007;52(5):556-564; discussion 565-567.

15. Hager DN, Krishnan JA, Hayden DL, Brower RG, Network ACT. Tidal volume reduction in patients with acute lung injury when plateau pressures are not high. Am J Respir Crit Care Med 2005; 172(10): 1241-1245.

16. Kallet RH, Branson RD. Respiratory controversies in the critical care setting. Do the NIH ARDS Clinical Trials Network PEEP/F $\mathrm{IO}_{2}$ tables provide the best evidence-based guide to balancing PEEP and $\mathrm{FIO}_{2}$ settings in adults? Respir Care 2007;52(4):461-475; discussion 475-477.

17. Terragni PP, Rosboch G, Tealdi A, Corno E, Menaldo E, Davini O, et al. Tidal hyperinflation during low tidal volume ventilation in acute respiratory distress syndrome. Am J Respir Crit Care Med 2007;175(2):160-166.

18. Laffey JG, O'croinin D, Mcloughlin P, Kavanagh BP. Permissive hypercapnia: role in protective lung ventilatory strategies. Intensive Care Med 2004;30(3):347-356.
19. Kregenow DA, Rubenfeld GD, Hudson LD, Swenson ER. Hypercapnic acidosis and mortality in acute lung injury. Crit Care Med 2006;34(1):1-7.

20. de Durante G, Del Turco M, Rustichini L, Cosimini P, Giunta F, Hudson LD, et al. ARDSNet lower tidal volume ventilatory strategy may generate intrinsic positive end-expiratory pressure in patients with acute respiratory distress syndrome. Am J Respir Crit Care Med 2002;165(9):1271-1274.

21. MacIntyre NR, Sessler CN. Are there benefits or harm from pressure targeting during lung-protective ventilation? Respir Care 2010; 55(2):175-180; discussion 180-183.

22. Davis K, Jr., Branson RD, Campbell RS, Porembka DT. Comparison of volume control and pressure control ventilation: is flow waveform the difference? J Trauma 1996;41(5):808-814.

23. Fujita Y, Fujino Y, Uchiyama A, Mashimo T, Nishimura M. High peak inspiratory flow can aggravate ventilator-induced lung injury in rabbits. Med SciMonit 2007;13(4):BR95-BR100.

24. Kotani M, Kotani T, Li Z, Silbajoris R, Piantadosi CA, Huang Y-CT. Reduced inspiratory flow attenuates IL-8 release and MAPK activation of lung overstretch. Eur Respir J 2004;24(2):238-246.

25. Rich PB, Reickert CA, Sawada S, Awad SS, Lynch WR, Johnson $\mathrm{KJ}$, et al. Effect of rate and inspiratory flow on ventilator-induced lung injury. J Trauma 2000;49(5):903-911.

26. MacIntyre NR, McConnell R, Cheng KC, Sane A. Patient-ventilator flow dyssynchrony: flow-limited versus pressure- limited breaths. Crit Care Med 1997;25(10):1671-1677.

27. Yang LY, Huang YC, MacIntyre N. Patient-ventilator synchrony during pressure-targeted versus flow-targeted small tidal volume assisted ventilation. J Crit Care 2007;22(3):252-257.

28. Kallet RH, Campbell AR, Dicker RA, Katz JA, Mackersie RC. Work of breathing during lung-protective ventilation in patients with acute lung injury and acute respiratory distress syndrome: a comparison between volume and pressure-regulated breathing modes. Respir Care 2005;50(12):1623-1631.

29. Mireles-Cabodevila E, Chatburn RL. Work of breathing in adaptive pressure control continuous mandatory ventilation. Respir Care 2009;54(11):1467-1472.

30. Branson RD. Dual control modes, closed loop ventilation, handguns, and tequila. Respir Care 2001;46(3):232-233.

31. Sottiaux TM. Patient-ventilator interactions during volume-support ventilation: asynchrony and tidal volume instability - a report of three cases. Respir Care 2001;46(3):255-262.

32. Jaber S, Delay J-M, Matecki S, Sebbane M, Eledjam J-J, Brochard L. Volume-guaranteed pressure-support ventilation facing acute changes in ventilatory demand. Intensive Care Med 2005;31(9): 1181-1188.

33. Jaber S, Sebbane M, Verzilli D, Matecki S, Wysocki M, Eledjam $\mathrm{JJ}$, et al. Adaptive support and pressure support ventilation behavior in response to increased ventilatory demand. Anesthesiology 2009; 110(3):620-627.

34. Schmidt UH, Hess DR. Does spontaneous breathing produce harm in patients with the acute respiratory distress syndrome? Respir Care 2010;55(6):784-786.

35. Leray V, Bourdin G, Flandreau G, Bayle F, Wallet F, Richard J-C, et al. A case of pneumomediastinum in a patient with acute respiratory distress syndrome on pressure support ventilation. Respir Care 2010;55(6):770-773.

36. Kallet RH, Siobal MS. Measuring dead space: does it really matter? Or, what are we waiting for? Respir Care 2010;55(3):350-352.

37. Nuckton TJ, Alonso JA, Kallet RH, Daniel BM, Pittet J-F, Eisner $\mathrm{MD}$, et al. Pulmonary dead-space fraction as a risk factor for death in the acute respiratory distress syndrome. N Engl J Med 2002; 346(17):1281-1286. 


\section{Approaches to Conventional Mechanical Ventilation of the Patient With ARDS}

38. Raurich JM, Vilar M, Colomar A, Ibáñez J, Ayestarán I, PérezBárcena J, et al. Prognostic value of the pulmonary dead-space fraction during the early and intermediate phases of acute respiratory distress syndrome. Respir Care 2010;55(3):282-287.

39. Lucangelo U, Bernabe F, Vatua S, Degrassi G, Villagra A, Fernandez R, et al. Prognostic value of different dead space indices in mechanically ventilated patients with acute lung injury and ARDS. Chest 2008;133(1):62-71.

40. Kallet RH, Alonso JA, Pittet JF, Matthay MA. Prognostic value of the pulmonary dead-space fraction during the first 6 days of acute respiratory distress syndrome. Respir Care 2004;49(9):1008-1014.

41. Pohlman MC, Mccallister KE, Schweickert WD, Pohlman AS, Nigos CP, Krishnan JA, et al. Excessive tidal volume from breath stacking during lung-protective ventilation for acute lung injury. Crit Care Med 2008;36(11):3019-3023.

42. Hess DR, Thompson BT. Patient-ventilator dyssynchrony during lung protective ventilation: what's a clinician to do? Crit Care Med 2006;34(1):231-233.

43. Ramnath VR, Hess DR, Thompson BT. Conventional mechanical ventilation in acute lung injury and acute respiratory distress syndrome (abstract). Clin Chest Med 2006;27(4):601-613, viii.

44. Papazian L, Forel J-M, Gacouin A, Penot-Ragon C, Perrin G, Loundou A, et al. Neuromuscular blockers in early acute respiratory distress syndrome. N Engl J Med 2010;363(12):1107-1116.

45. Cheng IW, Eisner MD, Thompson BT, Ware LB, Matthay MA, Network ARDS. Acute effects of tidal volume strategy on hemodynamics, fluid balance, and sedation in acute lung injury. Crit Care Med 2005;33(1):63-70; discussion 239-240.

46. Kahn JM, Andersson L, Karir V, Polissar NL, Neff MJ, Rubenfeld GD. Low tidal volume ventilation does not increase sedation use in patients with acute lung injury. Crit Care Med 2005; 33(4):766-771.

47. Gajic O, Dara SI, Mendez JL, Adesanya AO, Festic E, Caples SM, et al. Ventilator-associated lung injury in patients without acute lung injury at the onset of mechanical ventilation. Crit Care Med 2004;32(9): 1817-1824.

48. Gajic O, Frutos-Vivar F, Esteban A, Hubmayr RD, Anzueto A. Ventilator settings as a risk factor for acute respiratory distress syndrome in mechanically ventilated patients. Intensive Care Med 2005;31(7):922-926.

49. Li G, Malinchoc M, Cartin-Ceba R, Venkata CV, Kor DJ, Peters $\mathrm{SG}$, et al. Eight-year trend of acute respiratory distress syndrome: a population-based study in Olmsted County, Minnesota. Am J Respir Crit Care Med 2011;183(1):59-66.

50. Schultz MJ, Haitsma JJ, Slutsky AS, Gajic O. What tidal volumes should be used in patients without acute lung injury? Anesthesiology 2007;106(6):1226-1231.

51. Yilmaz M, Keegan MT, Iscimen R, Afessa B, Buck CF, Hubmayr $\mathrm{RD}$, et al. Toward the prevention of acute lung injury: protocolguided limitation of large tidal volume ventilation and inappropriate transfusion. Crit Care Med 2007;35(7):1660-1666.

52. Mascia L, Mastromauro I, Viberti S. High tidal volume as a predictor of acute lung injury in neurotrauma patients. Minerva Anestesiologica 2008;74(6):325-327.

53. Mascia L, Zavala E, Bosma K, Pasero D, Decaroli D, Andrews P, et al. High tidal volume is associated with the development of acute lung injury after severe brain injury: an international observational study. Crit Care Med 2007;35(8):1815-1820.

54. Mascia L, Pasero D, Slutsky AS, Arguis MJ, Berardino M, Grasso $\mathrm{S}$, et al. Effect of a lung protective strategy for organ donors on eligibility and availability of lungs for transplantation: a randomized controlled trial. JAMA 2010;304(23):2620-2627.
55. Thompson BT, Hayden D, Matthay MA, Brower R, Parsons PE. Clinicians' approaches to mechanical ventilation in acute lung injury and ARDS. Chest 2001;120(5):1622-1627.

56. Young MP, Manning HL, Wilson DL, Mette SA, Riker RR, Leiter JC, et al. Ventilation of patients with acute lung injury and acute respiratory distress syndrome: has new evidence changed clinical practice? Crit Care Med 2004;32(6):1260-1265.

57. Esteban A, Ferguson ND, Meade MO, Frutos-Vivar F, Apezteguia $\mathrm{C}$, Brochard L, et al. Evolution of mechanical ventilation in response to clinical research. Am J Respir Crit Care Med 2008; 177(2):170-177.

58. Checkley W, Brower R, Korpak A, Thompson BT; ARDS Network Investigators. Effects of a clinical trial on mechanical ventilation practices in patients with acute lung injury. Am J Respir Crit Care Med 2008;177(11):1215-1222.

59. Cooke CR, Kahn JM, Watkins TR, Hudson LD, Rubenfeld GD. Cost-effectiveness of implementing low-tidal volume ventilation in patients with acute lung injury. Chest 2009;136(1):79-88.

60. Herasevich V, Tsapenko M, Kojicic M, Ahmed A, Kashyap R, Venkata $\mathrm{C}$, et al. Limiting ventilator-induced lung injury through individual electronic medical record surveillance. Crit Care Med 2011;39(1):34-39.

61. Cole A, Weller S, Sykes M. Inverse ratio ventilation compared with PEEP in adult respiratory failure. Intensive Care Med 1984;10(5): 227-232.

62. Gurevitch MJ, Van Dyke J, Young ES, Jackson K. Improved oxygenation and lower peak airway pressure in severe adult respiratory distress syndrome. Treatment with inverse ratio ventilation. Chest 1986;89(2):211-213.

63. Tharratt RS, Allen RP, Albertson TE. Pressure controlled inverse ratio ventilation in severe adult respiratory failure. Chest 1988; 94(4):755-762.

64. Abraham E, Yoshihara G. Cardiorespiratory effects of pressure controlled inverse ratio ventilation in severe respiratory failure. Chest 1989;96(6):1356-1359.

65. Lain D, DiBenedetto R, Morris S, Van Nguyen A, Saulters R, Causey D. Pressure control inverse ratio ventilation as a method to reduce peak inspiratory pressure and provide adequate ventilation and oxygenation. Chest 1989;95(5):1081-1088.

66. Marcy TW, Marini JJ. Inverse ratio ventilation in ARDS. Rationale and implementation. Chest 1991;100(2):494-504.

67. Mercat A, Graïni L, Teboul JL, Lenique F, Richard C. Cardiorespiratory effects of pressure-controlled ventilation with and without inverse ratio in the adult respiratory distress syndrome. Chest 1993; 104(3):871-875.

68. Muñoz J, Guerrero JE, Escalante JL, Palomino R, De La Calle B. Pressure-controlled ventilation versus controlled mechanical ventilation with decelerating inspiratory flow. Crit Care Med 1993;21(8): 1143-1148.

69. Lessard MR, Guérot E, Lorino H, Lemaire F, Brochard L. Effects of pressure-controlled with different I:E ratios versus volume-controlled ventilation on respiratory mechanics, gas exchange, and hemodynamics in patients with adult respiratory distress syndrome. Anesthesiology 1994;80(5):983-991.

70. Mercat A, Titiriga M, Anguel N, Richard C, Teboul J. Inverse ratio ventilation $(\mathrm{I} / \mathrm{E}=2 / 1)$ in acute respiratory distress syndrome: a six-hour controlled study. Am J Respir Crit Care Med 1997;155(5): 1637-1642.

71. Zavala E, Ferrer M, Polese G, Masclans JR, Planas M, Milic-Emili $\mathrm{J}$, et al. Effect of inverse I:E ratio ventilation on pulmonary gas exchange in acute respiratory distress syndrome. Anesthesiology 1998;88(1):35-42. 


\section{Approaches to Conventional Mechanical Ventilation of the Patient With ARDS}

72. Shanholtz C, Brower R. Should inverse ratio ventilation be used in adult respiratory distress syndrome? Am J Respir Crit Care Med 1994;149(5):1354-1358.

73. Kacmarek RM, Hess D. Pressure-controlled inverse-ratio ventilation: panacea or auto-PEEP? Respir Care 1990;35(10):945-948.

74. Duncan S, Rizk N, Raffin T. Inverse ratio ventilation. PEEP in disguise? Chest 1987;92(3):390-392.

75. Esteban A, Anzueto A, Frutos F, Alía I, Brochard L, Stewart TE, et al. Characteristics and outcomes in adult patients receiving mechanical ventilation: a 28-day international study. JAMA 2002;287(3): 345-355.

76. Ferguson ND, Frutos-Vivar F, Esteban A, Anzueto A, Alía I, Brower RG, et al. Airway pressures, tidal volumes, and mortality in patients with acute respiratory distress syndrome. Crit Care Med 2005;33(1): 21-30.

77. Brower RG, Lanken PN, MacIntyre N, Matthay MA, Morris A, Ancukiewicz M, et al. Higher versus lower positive end-expiratory pressures in patients with the acute respiratory distress syndrome. N Engl J Med 2004;351(4):327-336.

78. Meade MO, Cook DJ, Guyatt GH, Slutsky AS, Arabi YM, Cooper DJ, et al. Ventilation strategy using low tidal volumes, recruitment maneuvers, and high positive end-expiratory pressure for acute lung injury and acute respiratory distress syndrome: a randomized controlled trial. JAMA 2008;299(6):637-645.

79. Mercat A, Richard J-CM, Vielle B, Jaber S, Osman D, Diehl J-L, et al. Positive end-expiratory pressure setting in adults with acute lung injury and acute respiratory distress syndrome: a randomized controlled trial. JAMA 2008;299(6):646-655.

80. Talmor D, Sarge T, Malhotra A, O'Donnell CR, Ritz R, Lisbon A, et al. Mechanical ventilation guided by esophageal pressure in acute lung injury. N Engl J Med 2008;359(20):2095-2104.

81. Villar J, Kacmarek RM, Pérez-Méndez L, Aguirre-Jaime A. A high positive end-expiratory pressure, low tidal volume ventilatory strategy improves outcome in persistent acute respiratory distress syndrome: a randomized, controlled trial. Crit Care Med 2006;34(5): 1311-1318.

82. Hess DR. How much PEEP? Do we need another meta-analysis? Respir Care 2011;56(5):710-713.

83. Gattinoni L, Caironi P, Cressoni M, Chiumello D, Ranieri VM, Quintel M, et al. Lung recruitment in patients with the acute respiratory distress syndrome. N Engl J Med 2006;354(17):1775-1786.

84. Caironi P, Cressoni M, Chiumello D, Ranieri M, Quintel M, Russo $\mathrm{SG}$, et al. Lung opening and closing during ventilation of acute respiratory distress syndrome. Am J Respir Crit Care Med 2010; 181(6):578-586.

85. Dasenbrook E, Needham DM, Brower RG, Fan E. Higher positive end-expiratory pressure in patients with acute lung injury: a systematic review and meta-analysis. Respir Care 2011;56(5):568-575.

86. Briel M, Meade M, Mercat A, Brower RG, Talmor D, Walter SD, et al. Higher vs lower positive end-expiratory pressure in patients with acute lung injury and acute respiratory distress syndrome: systematic review and meta-analysis. JAMA 2010;303(9):865-873.

87. Oba Y, Thameem DM, Zaza T. High levels of PEEP may improve survival in acute respiratory distress syndrome: a meta-analysis. Respir Med 2009;103(8):1174-1181.

88. Phoenix SI, Paravastu S, Columb M, Vincent J-L, Nirmalan M. Does a higher positive end expiratory pressure decrease mortality in acute respiratory distress syndrome? A systematic review and metaanalysis. Anesthesiology 2009;110(5):1098-1105.

89. Putensen C, Theuerkauf N, Zinserling J, Wrigge H, Pelosi P. Metaanalysis: ventilation strategies and outcomes of the acute respiratory distress syndrome and acute lung injury. Ann Intern Med 2009; 151(8):566-576.
90. Grasso S, Fanelli V, Cafarelli A, Anaclerio R, Amabile M, Ancona $\mathrm{G}$, et al. Effects of high versus low positive end-expiratory pressures in acute respiratory distress syndrome. Am J Respir Crit Care Med 2005;171(9):1002-1008.

91. Grasso S, Stripoli T, De Michele M, Bruno F, Moschetta M, Angelelli G, et al. ARDSnet ventilatory protocol and alveolar hyperinflation: role of positive end-expiratory pressure. Am J Respir Crit Care Med 2007;176(8):761-767.

92. Grasso S, Stripoli T, Sacchi M, Trerotoli P, Staffieri F, Franchini D, et al. Inhomogeneity of lung parenchyma during the open lung strategy: a computed tomography scan study. Am J Respir Crit Care Med 2009;180(5):415-423.

93. Suter PM, Fairley B, Isenberg MD. Optimum end-expiratory airway pressure in patients with acute pulmonary failure. N Engl J Med 1975;292(6):284-289.

94. Harris RS. Pressure-volume curves of the respiratory system. Respir Care 2005;50(1):78-98; discussion 98-99.

95. Harris RS, Hess DR, Venegas JG. An objective analysis of the pressure-volume curve in the acute respiratory distress syndrome. Am J Respir Crit Care Med 2000;161(2 Pt 1):432-439.

96. Mergoni M, Martelli A, Volpi A, Primavera S, Zuccoli P, Rossi A. Impact of positive end-expiratory pressure on chest wall and lung pressure-volume curve in acute respiratory failure. Am J Respir Crit Care Med 1997;156(3 Pt 1):846-854.

97. Owens RL, Hess DR, Malhotra A, Venegas JG, Harris RS. Effect of the chest wall on pressure-volume curve analysis of acute respiratory distress syndrome lungs. Crit Care Med 2008;36(11):2980-2985.

98. Ranieri VM, Brienza N, Santostasi S, Puntillo F, Mascia L, Vitale N, et al. Impairment of lung and chest wall mechanics in patients with acute respiratory distress syndrome: role of abdominal distension. Am J Respir Crit Care Med 1997;156(4 Pt 1):1082-1091.

99. Dall'ava-Santucci J, Armaganidis A, Brunet F, Dhainaut JF, Nouira S, Morisseau D, et al. Mechanical effects of PEEP in patients with adult respiratory distress syndrome. J Appl Physiol 1990;68(3): 843-848.

100. Puybasset L, Gusman P, Muller JC, Cluzel P, Coriat P, Rouby JJ. Regional distribution of gas and tissue in acute respiratory distress syndrome. III. Consequences for the effects of positive end-expiratory pressure. CT Scan ARDS Study Group. Intensive Care Med 2000;26(9):1215-1227.

101. Hickling KG. Reinterpreting the pressure-volume curve in patients with acute respiratory distress syndrome. Curr Opin Crit Care 2002; 8(1):32-38.

102. Grooms DA, Sibole SH, Tomlinson JR, Marik PE, Chatburn RL. Customization of an open lung ventilation strategy to treat a case of life threatening acute respiratory distress syndrome. Respir Care 2011;56(4):514-519.

103. Grasso S, Terragni P, Mascia L, Fanelli V, Quintel M, Herrmann P, et al. Airway pressure-time curve profile (stress index) detects tidal recruitment/hyperinflation in experimental acute lung injury. Crit Care Med 2004;32(4):1018-1027.

104. Gattinoni L, Pelosi P, Suter PM, Pedoto A, Vercesi P, Lissoni A. Acute respiratory distress syndrome caused by pulmonary and extrapulmonary disease. Different syndromes? Am J Respir Crit Care Med 1998;158(1):3-11.

105. Hess DR, Bigatello LM. The chest wall in acute lung injury/acute respiratory distress syndrome. Curr Opin Crit Care 2008;14(1):94-102.

106. Piraino T, Cook DJ. Optimal PEEP guided by an esophageal balloon. Respir Care 2011;56(4):510-513.

107. Loring SH, O’Donnell CR, Behazin N, Malhotra A, Sarge T, Ritz R, et al. Esophageal pressures in acute lung injury: do they represent artifact or useful information about transpulmonary pressure, chest wall mechanics, and lung stress? J Appl Physiol 2010;108(3):515-522. 


\section{Approaches to Conventional Mechanical Ventilation of the Patient With ARDS}

108. Talmor D, Sarge T, O’Donnell CR, Ritz R, Malhotra A, Lisbon A, et al. Esophageal and transpulmonary pressures in acute respiratory failure. Crit Care Med 2006;34(5):1389-1394.

109. Talmor DS, Fessler HE. Are esophageal pressure measurements important in clinical decision-making in mechanically ventilated patients? Respir Care 2010;55(2):162-172; discussion 172-174.

110. Girgis K, Hamed H, Khater Y, Kacmarek RM. A decremental PEEP trial identifies the PEEP level that maintains oxygenation after lung recruitment. Respir Care 2006;51(10):1132-1139.

111. Hickling KG. Best compliance during a decremental, but not incremental, positive end-expiratory pressure trial is related to openlung positive end-expiratory pressure: a mathematical model of acute respiratory distress syndrome lungs. Am J Respir Crit Care Med 2001;163(1):69-78.

112. Huh JW, Jung H, Choi HS, Hong S-B, Lim C-M, Koh Y. Efficacy of positive end-expiratory pressure titration after the alveolar recruitment manoeuvre in patients with acute respiratory distress syndrome. Crit Care 2009;13(1):R22.

113. Branson RD, Johannigman JA. Innovations in mechanical ventilation. Respir Care 2009;54(7):933-947.
114. Owens RL, Stigler WS, Hess DR. Do newer monitors of exhaled gases, mechanics, and esophageal pressure add value? Clin Chest Med 2008;29(2):297-312, vi-vii.

115. Bouhemad B, Brisson H, Le-Guen M, Arbelot C, Lu Q, Rouby JJ. Bedside ultrasound assessment of positive end-expiratory pressureinduced lung recruitment. Am J Respir Crit Care Med 2011;183(3): 341-347.

116. Costa EL, Borges JB, Melo A, Suarez-Sipmann F, Toufen C Jr, Bohm SH, Amato MB. Bedside estimation of recruitable alveolar collapse and hyperdistension by electrical impedance tomography. Intensive Care Med 2009;35(6):1132-1137.

117. Victorino JA, Borges JB, Okamoto VN, Matos GF, Tucci MR, Caramez MP, et al. Imbalances in regional lung ventilation: a validation study on electrical impedance tomography. Am J Respir Crit Care Med 2004;169(7):791-800.

118. Chiumello D, Carlesso E, Cadringher P, Caironi P, Valenza F, Polli $\mathrm{F}$, et al. Lung stress and strain during mechanical ventilation for acute respiratory distress syndrome. Am J Respir Crit Care Med 2008;178(4):346-355. 